\title{
THE LYNX SPIDER GENUS OXYOPES IN MEXICO AND CENTRAL AMERICA (ARANEAE:OXYOPIDAE) ${ }^{1}$
}

\author{
By Allen R. Brady \\ Dept. of Biology, Hope College \\ Holland, Michigan 49423
}

\section{INTRODUCTION}

This is the second in a projected series of papers on the Neotropical Oxyopidae. In this study I6 species of Oxyopes are recorded from Mexico and Central America. Of these, i I are predominately Mexican and Central American, four are more abundant in America, north of Mexico, and one is widely distributed throughout Mexico, North and Central America. Numerous specimens from Mexico and Central America were examined during this study. Collections available from the Museum of Comparative Zoology and the American Museum of Natural History provided an abundance of specimens from certain areas, such as the Panama Canal Zone. However, some regions of Mexico and Central America are poorly collected. Additional specimens came from field studies during several summers in Mexico (1969-71), Costa Rica (1972), and Panama (1972).

Named species of Oxyopes from Mexico and Central America were often inadequately described and figured and there was some confusion as to the correct names of several species, males and females having been separately described. In addition, little was known of the geographic ranges nor was there any clear concept of the evolutionary relationships of Neotropical Oxyopes to each other or to their North American relatives.

Certain species of Oxyopes are extremely abundant in areas of grassy or herbaceous vegetation. For example, O. salticus and $O$. flavus constituted as much as $20 \%$ of the total number of spiders taken in sweeping vegetation (0.5- $\mathrm{I} \mathrm{m}$ in height) in some coastal areas of Guerrero and Veracruz. Judging from their abundance, these spiders are evidently important predators of insects within these habitats. The species of Oxyopes observed were all active during the day. They ran swiftly over the plants where they occurred and when disturbed exhibited characteristic erratic leaps which allow them to be immediately recognized in the field. Although Oxyopes do not actively pursue their prey by sight, they are much

${ }^{1}$ Manuscript received by the editor March 25, 1975 
more active than thomisids, and exhibit a general "searching" behavior when observed. Long spines on the legs, another field characteristic of lynx spiders, are apparently used to subdue prey. Much remains to be learned about prey capture and other forms of behavior.

The systematic findings in this work are based largely upon morphological studies and distributional data. Ecological and behavioral information has been incorporated where available. Members of the $O$. acleistus species group and the $O$. tridens group are distinguished as much by their ecology as their morphology. Species in the former group are found in areas of moderately luxuriant herbaceous vegetation, while species of the latter group have been found chiefly in rather dry, rocky areas with relatively scanty vegetation. Color patterns of the two species groups generally reflect their surroundings. Species of the $O$. tridens group are generally black and white, fitting well the rather drab, gray backgrounds where they occur. Members of the $O$. acleistus group blend more appropriately with their background coloration of green, and are often deceptively iridescent in sunlight. Members of the tridens group have a more robust fourth pair of legs, presumably fitted for saltatory locomotion in a more open habitat.

Systematic studies, such as this one, often provide a foundation for more detailed investigations into the biology of organisms. I hope that this paper will not only fill the need for a basic morphological revision, but stimulate further investigations of the ecology and behavior of Oxyopes.

\section{ACKNOWLEDGMENTS}

To fully acknowledge help with this paper, I must trace its inception back to a study begun in 1963 while I was a student at the Museum of Comparative Zoology, Harvard University. The major thrust of this early work resulted in the publication of a monograph on the Oxyopidae of North America, north of Mexico (Brady, 1964). A grant from the Evolutionary Biology Committee, Biological Laboratories, Harvard University, made possible a three week visit to the British Museum (Natural History) in the summer of 1963. Here several of the type specimens of Oxyopes of F.O.P.-Cambridge were examined and drawn for the first time (Figs. 8o-83, 84-87, $96,97)$.

The initial writing and preparation of this paper for publication began in I973. The types of F.O.P.-Cambridge were examined 
again. I appreciate the courtesy of Mr. F. R. Wanless, Department of Zoology (Arachnida), British Museum (Natural History) for making this possible

I am especially grateful to Dr. H. W. Levi of the Museum of Comparative Zoology, Harvard University, who has loaned specimens, offered helpful criticism, and aided in other ways the preparation of this publication. Special acknowledgement is due to the late Dr. A. M. Chickering whose collections, now housed in the Museum of Comparative Zoology, provided a wealth of material. I am also indebted to Dr. W. J. Gertsch and Dr. N. I. Platnick for the loan of specimens from the American Museum of Natural History.

During the 1972-73 academic year I was appointed Visiting Professor in the Department of Zoology, University of Florida at Gainesville. For facilities and various courtesies there, I wish to thank Dr. Brian K. McNab, who was then Acting Chairman. For their helpfulness and encouragement of research, I would like to especially thank Dr. Jonathan Reiskind, Dr. H. K. Wallace, and Dr. John Anderson also of the University of Florida.

Special thanks are due to my wife Sara who has aided in proof reading and accepted my long absences during the preparation of this paper.

A 1974 Summer Faculty Grant from Hope College aided in preparation of this paper. National Science Foundation Grant GB-I3925 helped to defray expenses connected with this study and permitted its publication.

\section{METHODS}

Measurements. All measurements listed are in millimeters. When available ten specimens of each sex were measured. The purpose of this was to give some idea of the variation to be expected within a species population. Measurements are presented in tabular form to facilitate comparisons and aid in their use.

Collection Records. Collection records for Mexico and Central America only are listed. Records north of Mexico are in earlier publications. Localities are listed geographically from north to south and from east to west. The number of specimens collected at each locality is indicated; the lower case "o" representing immature specimens.

Drawings. Epigyna and palps were drawn after they were scraped free of hair and large setae removed. Internal genitalia of the female were drawn after clearing in clove oil. 


\section{SPECIES GROUPS OF OXYOPES}

The 16 species of Oxyopes reported from Mexico and Central America in this paper can be combined into five distinct groups. These species groups are based primarily upon the shape or form of the body (morphology), color pattern, relative lengths of legs, and structure of the male and female reproductive organs. For the sake of completeness, five species of Oxyopes recorded only from north of Mexico are included in the discussion below.

Acleistus Group. This species group may be arbitrarily subdivided into two subgroups: one containing chiapas, summus, occidens, and aglossus; the other containing tibialis, acleistus, bifidus, and bifissus. In the first sub-group only aglossus is not recorded from Mexico or Central America. All of the second group are found in Mexico. In light of comparative morphology, genitalic structure, color patterns, and geographical distribution, a dendrogram representing the relationships of the eight species in this species group is shown in Diagram I.

Important considerations in grouping species in Diagram I were as follows: (I) chiapas and summus have similar internal female genitalia (compare Fig. 33 to Fig. 3I) and the male palpi are alike (compare Figs. 92, 93 to Figs. 90, 91); (2) occidens and aglossus are similar in coloration (compare figs. 7, 8 to figs. 9-12 of Brady, 1964), female reproductive organs (compare figs. 23, 24 to figs. 2I, 22 of Brady, 1964), and male palpi (compare figs. 33, 34 to figs.

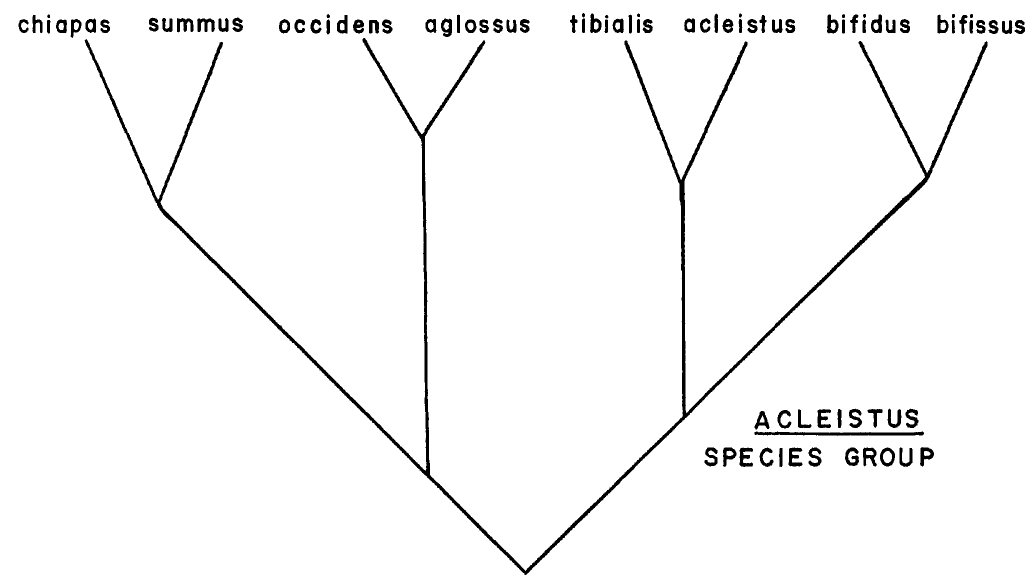

Diagram 1. 
39, 40 of Brady, 1964); (3) tibialis and acleistus are much alike in color pattern (compare Figs. 5, 6 with figs. I-6 of Brady, I964), female reproductive organs (compare Figs. 35, 36 with figs. 13-20 of Brady, 1964), and male palpi (compare Figs. 94-97 with figs. 35-38 of Brady, 1964); (4) bifidus and bifissus have similar color patterns (compare Figs. I, 2 with Figs. 3, 4) internal female genitalia (compare Figs. 25, 27 with Fig. 37) and male palpi (compare Figs. 78-81 with Figs. 84-89).

It should be stressed that these are observations that lend credibility to Diagram I as it is conceived. The relationships of the species is actually much more complex. For example, it appears that tibialis may be near the ancestral stem of both acleistus and aglossusoccidens, although it shows more similarities to the former species. The diagram is a simplification of relationships. This is certainly a case where additional specimens subjected to numerical analyses of multiple characters might yield important information about relationships.

Tridens Group. This species group may also be arbitrarily subdivided into two subgroups: one containing apollo and artemis; the other cougar, lynx, tridens, pardus, panther, ocelot, cornutus, and felinus. In the first subgroup only apollo has been found in Mexico. In the second subgroup pardus and lynx are represented by unique specimens (Brady, 1964), and cougar is recorded only from the southeastern United States (Brady, 1969).

Utilizing comparative morphology, genitalic structure, color patterns, and distribution patterns, a dendrogram representing the hypothetical relationships of the eight species in the second subgroup is shown in Diagram 2. The well developed tibial apophyses and palpal sclerites of $O$. apollo and $O$. artemis males, as well as strongly developed fourth legs in both sexes, place them near the eight species in Diagram 2. There is considerable resemblance in color among the species of the tridens group that I have seen in the field. This is not so apparent in preserved specimens. Members of this group are not often taken in sweep-nets, but seem to frequent rather dry areas with scanty, low-growing vegetation. Some are found at high elevations. When more information is available, this group may be as well defined ecologically as morphologically.

Important considerations in grouping species in Diagram 2 were as follows: ( I) cougar, lynx, tridens, pardus, and panther have welldeveloped tibial apophyses on the male palpi; (2) cougar and lynx have very similar palpi (compare figs. 9, Io of Brady, 1969, with figs. 66, 67 of Brady, 1964); (3) tridens and pardus have similar 
palpi (compare figs. 70, 7I and figs. 68, 69 of Brady, 1964); (4) tridens and panther have color patterns (compare figs. 62, 63 of Brady, I964 with figs. 5, 6 of Brady, 1969 and Figs. 15, 16) and epigyna alike (compare figs. 53-55 of Brady, I964 with figs. I6, I7 of Brady, I 969 and Figs. 45, 46). It is possible that panther is the female of pardus.

Also (I) ocelot, cornutus, and felinus have predominant black and white color patterns, but they lack prominent tibial apophyses. Oxyopes felinus has a small knob on the tibial segment (Figs. IO2, I03), (2) the male palpi (Figs. IOO-IO5), as well as the epigyna and internal genitalia (Figs. 39-44) of these three species are much alike. Oxyopes ocelot is the most distinctive of the three.

Color patterns in Oxyopes seem to be a conservative feature and are useful in determining relationships. It should be pointed out, however, that color is often altered by scraping off hair during handling and to a lesser extent by preservation in alcohol. Also, one needs an adequate sample of specimens to determine the color pattern norm, because of individual variation within a population and geographic variation within the species. The structure and arrangement of male palpal sclerites and apophyses as well as external and internal structure of the female genitalia are the most reliable criteria for determining species relationships. Because of a need for more specimens from certain critical areas in Mexico and Central America the proposed dendrograms must be considered strictly tentative as based on the available material.

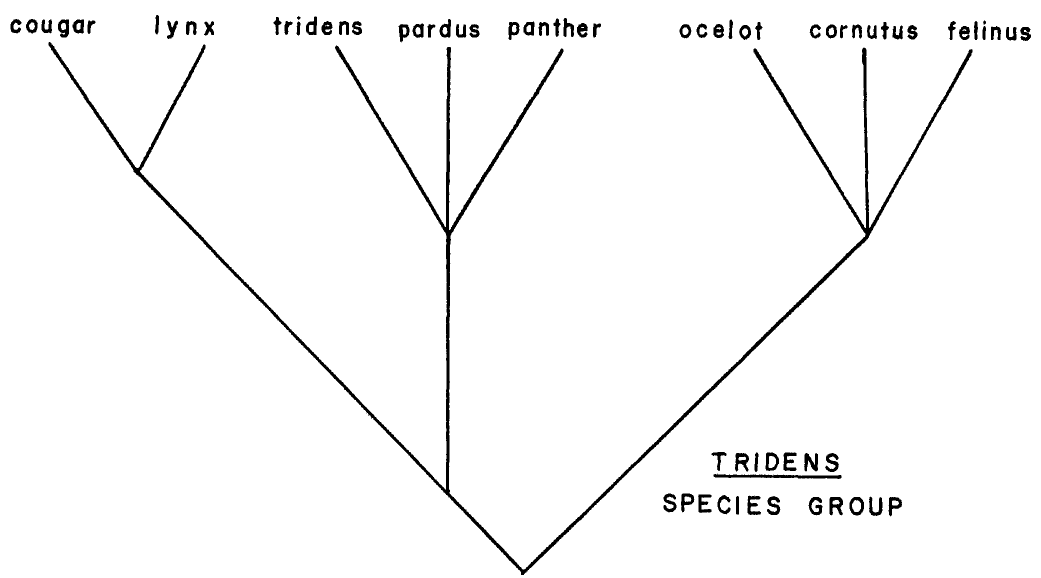

Diagram 2. 
The remaining three species of Oxyopes found in Mexico and Central America are $O$. scalaris, $O$. salticus, and $O$. flavus. They are different from all other species found in this region.. In context with the other species they would constitute distinct monotypic species groups.

Oxyopes scalaris is essentially a temperate species whose southern limit of range extends into the northern Mexican plateau (Map 4). Oxyopes salticus is found in the United States and occurs throughout Mexico and Central America (Map 3). Oxyopes flavus does not occur north of Mexico (Map 4).

\section{UNIDENTIFIABLE SPECIES}

Nathan Banks ( 1898 ) described O. acutus based upon several young males from La Chaparos, Sierra Laguna, and Hermosillo, Mexico and an adult female from Baja California. The female which is figured by Banks, is $O$. scalaris Hentz. One of the immature males is labelled as a type in the collection of the Museum of Comparative Zoology. The color pattern of this specimen matches that of several species in the $O$. tridens complex. Oxyopes acutus has appeared only as an entry in faunal lists in the zoological literature. The name has not been associated with any specimens since the original description by Banks. For that reason and because of the difficulty in accurately determining the species that the immature type represents, I think it best to consider $O$. acutus as a nomen dubium.

The type female of $O$. actophilus described by Chamberlin (1924). has apparently been lost. The description, based upon an immature female type, is not adequate enough to determine the species with any accuracy. Therefore, I think that $O$. actophilus is also best considered a nomen dubium.

\section{KEY TO SPECIES OF OXYOPES}

\section{Females}

Ia. Leg I longer than leg IV.

Ib. Leg IV longer than leg I. .......................................... 9

2a. Body length $7.2 \mathrm{~mm}$ or less. .......................................... 3

2b. Body length greater than $7.2 \mathrm{~mm}$. Color yellow with black markings. Pattern as in Figures 13, I4. Epigynum as in Figures $47-54$. 
3a. Distinct mid-ventral stripes on femora I-II. ................... 6

3b. No distinct mid-ventral stripes on femora I-II. ................ 4

4a. Thin vertical black stripes beginning under AME and continuing to subdistal region of chelicerae as in Figure 3. ....... 5

4b. No thin black stripes as in Figure 3. Russet brown, dark brown, or gray in general appearance (figs. 89, 90, 97-99 of Brady, 1964). scalaris

5a. Found in Arizona, Baja California. Probably limited to Sonoran Desert region (figs. 7, 8, 23, 24 of Brady, I964). occidens

5b. Found south of Sonoran Desert region (Map I). Figures 3, $4,37,38$. bifissus

6a. Epigynum with an anteriorly directed scape (Fig. 24). Color pattern as in Figures II, 12. salticus

6b. Epigynum without an anteriorly directed scape. Color pattern not as above.

7a. Found in northeastern Mexico (Map I). Color pattern as in figure $\mathrm{I}-6$, epigynum as in figures $13-20$ of Brady, 1964 .

acleistus

7b. Not found in northeastern Mexico. Occurring westward or southward of acleistus.

8a. Color pattern as in Figures I, 2. Epigynum as in Figures 25-30. bifidus

8b. Color pattern as in Figures 5, 6. Epigynum as in Figures 35,36 . tibialis

8c. Color pattern as in Figures 7, 8. Epigynum as in Figures 33, 34. chiapas

8d. Color pattern as in Figures 9, Io. Epigynum as in Figures $31,32$. summus

9a. Color pattern as in Figures 15, I6. Epigynum as in Figures $45,46$. panther

9b. Color pattern as in Figures 17, 18. Epigynum as in Figures 4I, 42. ocelot

9c. Color pattern as in Figures 19, 20. Epigynum as in Figures 43, 44. cornutus

9d. Color pattern as in Figures 2I, 22. Epigynum as in Figures 39, 40.

felinus

9e. Color pattern as in figures 45,46 of Brady, I964. Epigynum as in figures 53,55 of Brady, 1964 . acleistus 


\section{KEY TO SPECIES OF OXYOPES}

\section{MALES}

Ia. Leg I longer than leg IV.

Ib. Leg IV longer than leg I.

2a. Body length $5 \mathrm{~mm}$ or less.

2b. Body length greater than $5 \mathrm{~mm}$. Color yellow with black markings. Pattern as in Figures 76, 77. Palpus illustrated in Figures 106, I07.

3a. Distinct mid-ventral black stripes on femora I-II. .............. 6

3b. No distinct mid-ventral stripes on femora I-II. ................... 4

4a. Thin vertical black stripes beginning under AME and continuing to subdistal region of chelicerae as in Figures 57, 59. 5

4b. No thin black stripes as in Figures 57, 59. Russet brown, dark brown, or gray in general appearance (figs. 87, 88, I06, I07 of Brady, 1964). scalaris

5a. Found in Arizona, Baja California. Probably limited to Sonoran Desert region (figs. 25, 26, 33, 34 of Brady, I964).

occidens

5b. Found south of Sonoran Desert region (Map I). Figures 57-60, 84-89.

bifissus

6a. With a well-developed retrolateral tibial apophysis as in Figures $94-97$.

6b. Without a well-developed retrolateral tibial apophysis as in Figures 94-97.

7a. Tarsus of palpus deeply concave, and with a brush of stiff hairs on the ventral surface of the patella. Color pattern as in Figures 73-75. Palpus as in Figures 98, 99. salticus

7b. Tarsus of palpus not deeply concave, and without a brush of stiff hairs on the ventral surface of the patella.

8a. Palpus illustrated in Figures 78-8r. bifidus

8b. Palpus illustrated in Figures 90, 9r. summus

8c. Palpus illustrated in Figures 92, 93. chiapas

9a. Found in northern Mexico and northward (Map I). Palpus illustrated in figures $35-38$ of Brady, I964. ............... acleistus

9b. Found in southern Mexico and southward (Map I). Palpus illustrated in Figures 94-97. tibialis

IOa. With a conspicuous apophysis on the patella of the palpus (figs. 70, $7 \mathrm{I}$ of Brady, 1964). tridens 
Iob. With a small apophysis on the patella of the palpus (figs. 74, 75 of Brady, 1964) or without a patellar apophysis. ........... I I

IIa. With a small apophysis on the patella of the palpus as in figures 74, 75 of Brady, 1964. Color pattern as in figures 72, 73 of Brady, 1964 . apollo

I Ib. Without an apophysis on the patella of the palpus. $\mathrm{I} 2$

12a. Palpus illustrated in Figures 100, IOI. ocelot I2b. Palpus illustrated in Figures 102, IO3. felinus

I2c. Palpus illustrated in Figures 104, 105. cornutus

\title{
SPECIES DESCRIPTIONS
}

\author{
Oxyopes acleistus Chamberlin \\ Map I.
}

Oxyopes acleistus Chamberlin, 1929, Ent. News, 40:19, fig. 3, ㅇ. Female holotype from Sanford, Seminole Co., Florida, in the American Museum of Natural History, examined. Roewer, 1954, Katalog der Araneae 2 (a) :330. Bonnet, 1958, Bibliographia Araneorum, 2(4):3223.

Oxyopes aureus Brady, 1964, Bull. Mus. Comp. Zool., 131(13) :457, figs. 1-4, 13-17, 27, 28, 35, 36, ô 우. Female holotype from Bentsen State Park, $6 \mathrm{mi}$. SW of Mission, Hidalgo Co., Texas, in the Museum of Comparative Zoology. NEW SYNONYMY.

Discussion. After seeing both individual and geographic variation of the epigynia of $O$. bifidus (Figs. 25-30), I am led to believe that the differences between $O$. aureus and $O$. acleistus are, at best, subspecific. The fact that the color patterns and the male palpi of these two species are much alike supports this position. After seeing the variance of certain taxonomic characters within some Mexican and Central American species, I am impressed with the similarities between $O$. aureus and $O$. acleistus. Therefore, I consider them conspecific here.

See Brady, 1964, pages 454-46o for figures, measurements, color descriptions, diagnoses, notes on natural history, and collection records north of Mexico.

Distribution. Florida, Louisiana, Texas and northern Mexico. (Map I).

Records. MEXICO, Tamaulipas. Rio Gualoliejo near Forólon, 16 April 1939, 0" oo (LID, B. Brown). San Luis Potosí. Huichihuayan, I9 May 1952, o (MAC, WJG, RS); 10 mi. N of Valles, 23 July 1945, (A. M. Dame). Nuevo Léon. Horsetail Falls, 7 July 1972, 우 \& (ARB). 


\section{Oxyopes occidens Brady \\ Map I.}

Oxyopes occidens Brady, 1964, Bull. Mus. Comp Zool., 131(13):464, figs. 7, 8, 23-26, 33, 34, 수 ㅇ․ Male holotype from Sabino Pond, Sabino Canyon, Santa Catalina Mtns., Pima Co., Arizona, in the Museum of Comparative Zoology.

Discussion. For figures, measurements, color descriptions, diagnosis, notes on natural history, and collection records north of Mexico, see Brady (1964), pages 464-467.

Distribution. Arizona, Baja California (Map I).

Record. MEXICO. Baja California. San José del Cabo, I896, 우 (NB).

\section{Oxyopes bifidus F.O.P.-Cambridge}

Figures I, 2, 25-30, 55, 56, 78-8I. Map I.

Oxyopes bifidus F.O.P.-Cambridge, 1902, Biologia Centrali-Americana, Arachnida, Araneidea, $2: 344$, pl. 32, figs. 20, 20a, $\hat{o}$. Male holotype from Acapulco, Guerrero, Mexico, in British Museum (Natural History), examined. Roewer, 1954, Katalog der Araneae, 2(a) :331. Bonnet, 1958, Bibliographia Araneorum, 2(4):3225.

Discussion. Oxyopes bifidus is one of the most common and widespread species of Oxyopes in Mexico and Central America. The epigyna of this species is remarkable for its variation in structure (Figs. 25-30). This variation is also characteristic of $O$. acleistus, a member of the same species group (see Brady, 1964, figs. 13-20).

Measurements. Ten females and ten males.

\begin{tabular}{|c|c|c|c|c|c|}
\hline FEMALES: & Mean & Range & & Mean & Range \\
\hline Clypeus & .518 & $.45-.58$ & Femur I & 2.42 & $2.1-2.8$ \\
\hline AME & .343 & $.30-.38$ & Patella-Tibia I & 3.01 & $2.7-3.7$ \\
\hline ALE & .625 & $.55-.68$ & Metatarsus I & 2.44 & $2.2-2.8$ \\
\hline PLE & 1.148 & $1.00-1.25$ & Tarsus I & .99 & $.8-1.3$ \\
\hline PME & .623 & $.55-.68$ & Total Length I & 8.86 & $7.8-10.4$ \\
\hline $\begin{array}{l}\text { Carapace } \\
\text { Width }\end{array}$ & 1.78 & $1.6-2.0$ & & & \\
\hline $\begin{array}{l}\text { Carapace } \\
\text { Length }\end{array}$ & 2.37 & $2.1-2.7$ & $\begin{array}{l}\text { Patella-Tibia II } \\
\text { Patella-Tibia III }\end{array}$ & $\begin{array}{l}2.72 \\
2.06\end{array}$ & $\begin{array}{l}2.4-3.1 \\
1.7-2.4\end{array}$ \\
\hline $\begin{array}{l}\text { Total } \\
\text { Length }\end{array}$ & 5.58 & $4.8-6.6$ & $\begin{array}{l}\text { Patella-Tibia IV } \\
\text { Total Length IV }\end{array}$ & $\begin{array}{l}2.40 \\
8.05\end{array}$ & $\begin{array}{l}2.2-2.8 \\
7.2-9.4\end{array}$ \\
\hline
\end{tabular}




\begin{tabular}{|c|c|c|c|c|c|}
\hline MALES: & Mean & Range & & Mean & Range \\
\hline Clypeus & .423 & $.38-.53$ & Femur I & 2.31 & $2.1-2.6$ \\
\hline AME & .313 & $.30-.35$ & Patella-Tibia I & 2.97 & $2.7-3.2$ \\
\hline ALE & .565 & $.53-.65$ & Metatarsus I & 2.81 & $2.5-3.2$ \\
\hline PLE & 1.015 & $.95-1.15$ & Tarsus I & 1.21 & $1.0-1.5$ \\
\hline PME & .555 & $.53-.63$ & Total Length I & 9.31 & $8.4-10.5$ \\
\hline $\begin{array}{l}\text { Carapace } \\
\text { Width }\end{array}$ & 1.62 & $1.5-1.9$ & & & \\
\hline $\begin{array}{l}\text { Carapace } \\
\text { Length }\end{array}$ & 2.12 & $2.0-2.5$ & $\begin{array}{l}\text { Patella-Tibia II } \\
\text { Patella-Tibia III }\end{array}$ & $\begin{array}{l}2.66 \\
1.97\end{array}$ & $\begin{array}{l}2.4-3.1 \\
1.8-2.3\end{array}$ \\
\hline $\begin{array}{l}\text { Total } \\
\text { Length }\end{array}$ & 4.30 & $4.0-5.0$ & $\begin{array}{l}\text { Patella-Tibia IV } \\
\text { Total Length IV }\end{array}$ & $\begin{array}{l}2.30 \\
7.88\end{array}$ & $\begin{array}{l}2.0-2.6 \\
7.2-9.0\end{array}$ \\
\hline
\end{tabular}

Color. Female. Face and chelicerae cream to pale orange, lighter along lower edge of clypeus. Darker brownish vertical stripes as in Figure I. Eye region dark brown or black, overlaid with white appressed hair.

Carapace cream to pale orange with darker brown markings as illustrated in Figure 2.

Dorsum of abdomen white to yellow medially, the cardiac area translucent; bounded on each side by brown as in Figure 2. Venter with broad, dark brown median stripe from epigastric furrow to base of spinnerets; bounded by lighter cream to yellow.

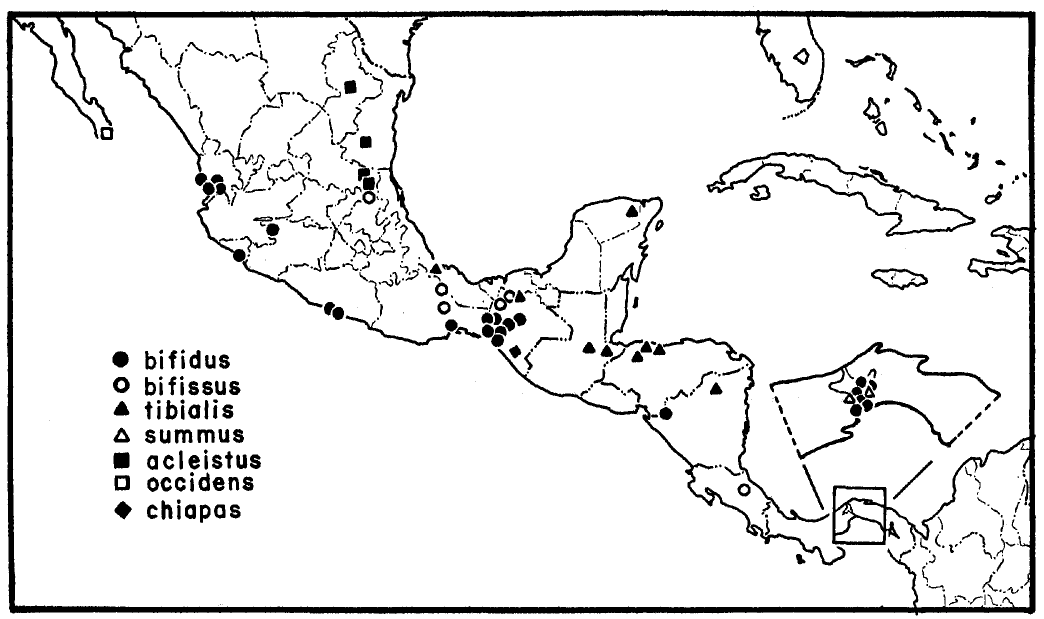

Map 1. 
Legs cream to yellow. Dark median stripe on ventral surface of femora I and II.

Labium and endites yellow to pale orange. Sternum cream to pale yellow.

Color. Male. Face and chelicerae yellow to pale orange with darker brown stripes as illustrated in Figure 55. Eye region dark brown to black. Cymbia of palpi dark brown to black.

Carapace yellow to pale orange with faint indications of more dusky markings as shown in Figure 56.

Dorsum of abdomen with median area cream to pale yellow, bordered laterally by dark brown as in Figure 56. Venter with broad median brown stripe from genital area to base of spinnerets. Lateral areas pale yellow, mottled with darker color.

Legs yellow. Ventral surface of femora I and II with a dark median stripe.

Labium and endites pale orange. Sternum yellow.

Diagnosis. Oxyopes bifidus is most closely related to $O$. bifissus as evidenced by coloration and morphology. The male palpi are very similar (compare Figs. 78-8I with Figs. 84-89), but distinct. The two species are easily separated by epigynal structure (compare Figs. 25-30 with Figs. 37-38). Preliminary collecting indicates that these two species are largely allopatric, $O$. bifidus occurring in western Mexico and Central America and $O$. bifissus in eastern Mexico with one record form Costa Rica.

Natural History. Oxyopes bifidus was collected in Panama and Costa Rica by sweeping tall grass and herbaceous vegetation. $O x$ yopes salticus was present in these same habitats in much greater numbers than $O$. bifidus. No differences were noted in the microhabitats of these two species.

Distribution. Western Mexico to Panama (Map I).

Records. MEXICO. Nayarit. Compostela, I2-I3 July 1972, $\sigma^{x}: 3$ ㅇ 우 :o (ARB, AJ) ; 6 mi. E of Las Varas, I3 July 1972, 400 (ARB) ; San Blas, I4 Sept. I957, ơ o (RD); 20 mi. S of Tepic, 4 Aug. I956, \& (WJG, VDR); Tepic, 6-7 Aug. 1955, o (BM). Guerrero. Acapulco, $\sigma^{7}$ (HHS), Pie de las Cuesta, $8 \mathrm{mi}$. W of Acapulco, 29 June I94I, o (LID). Colima. Boca de Pascuales, Io Jan. 1943, ㅇ (FB). Michoacan. $25 \mathrm{mi}$. E of Mazamitla, 2 Aug. 1956, ot + o (WJG, VDR). Oaxaca. Tehuantepec, 26 Aug. 1947, ㅇ (HMW). Chiapas. Arriaga, I-2 Sept. 1947, ơ ơ + , Chiapa, 6 Sept. 1947, ot, Cintalapa, I7 Sept. 1947, 3 q $q$, Las Cruzes, 18 Sept. 1947, $\sigma^{\pi}$, Río de las Flores, 15 Sept. 1947, 4 우우 :o, I6 Sept. 1947, ㅇ (HMW); Tonala, Aug. 1909, d $0^{x}$ 우 우 o (AP). 

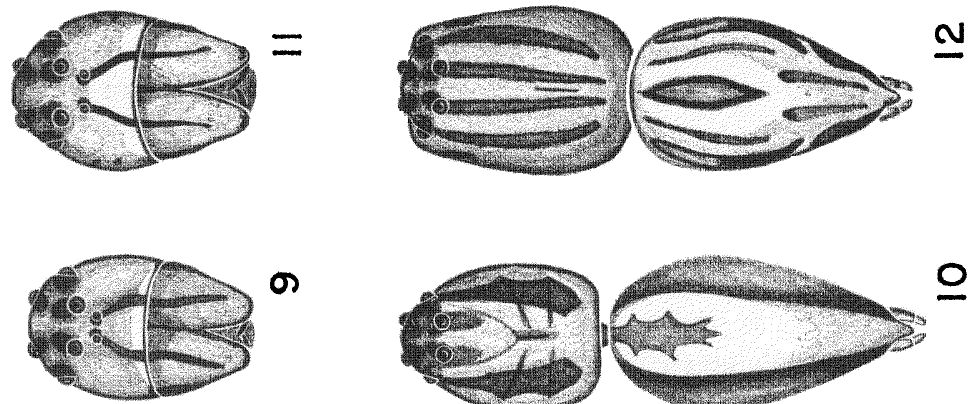

क
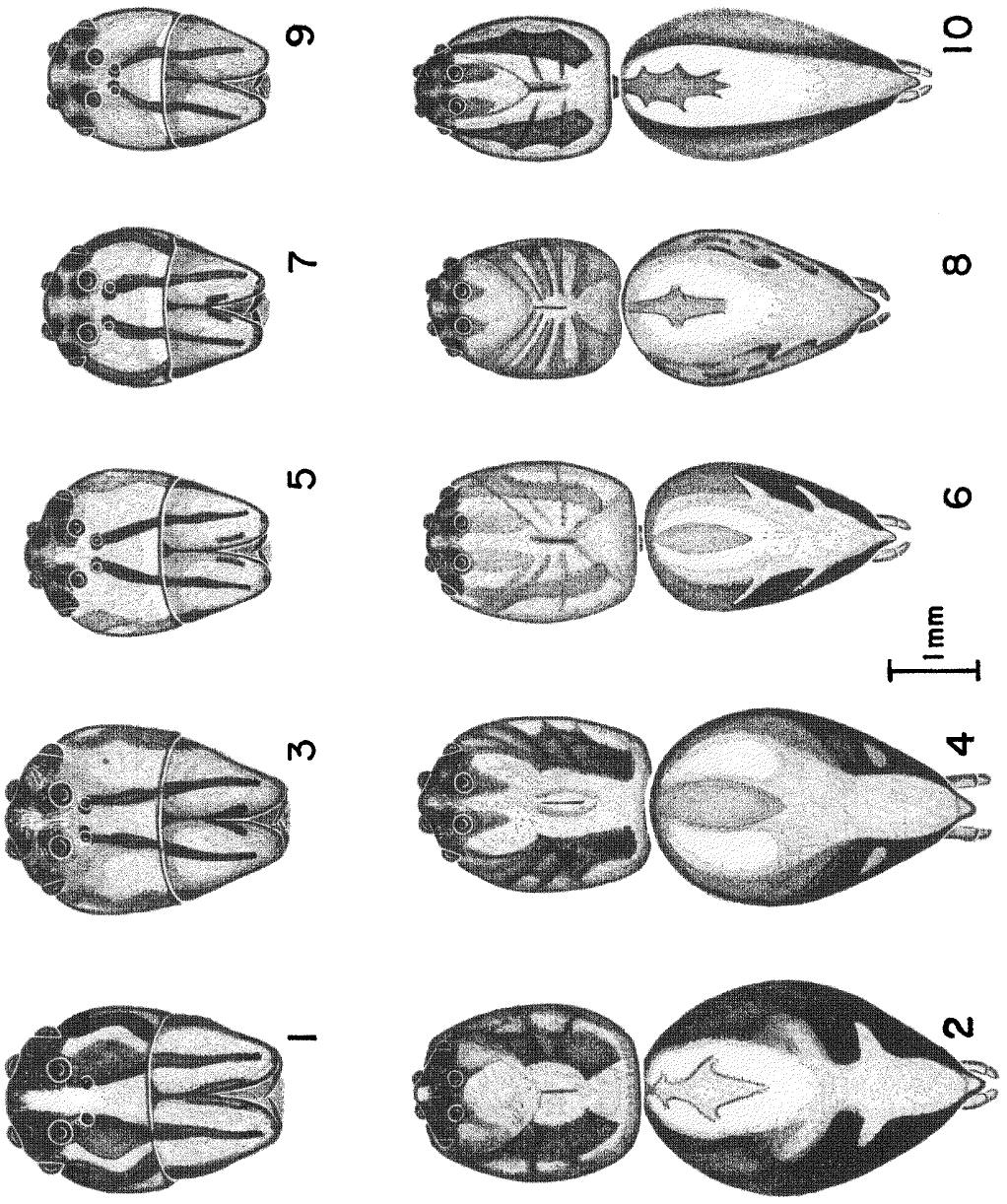
NICARAGUA. San Marcos, ơ (CTB).

PANAMA. Arraiján, 6-9 July 1950, 우, Chilibre, 8 July 1950, 5 우우 (AMC). Canal Zone. Balboa, I-14 Mar. 1954, ox, Feb.Aug. 1957, o $0^{\pi}$ (WEL); Chiva, 23 July 1954, \& oo (AMC) ; Cocoli, 3 Dec. 1956, o , 26 Jan. 1958, ㅇ (WEL) ; Experimental Gardens, I2-13 July 1954, o $0^{x}+$, I2 Aug. 1954, + , Forest Reserve, IO-I2 Aug. 1939, + , 23 July I950, $\sigma^{\star}, 30$ July 1950, $40^{x} 0^{x}: 0,25-28$ July $1954,30^{x} 0^{x}: 7$ 우 :00, 24 Dec. 1957, $0^{x}:$ 9 우 :0, 2I-22 Jan. 1958, $70^{x} 0^{x}: 19$ 우우 :1300, 29 Jan. 1958, $0^{x}:$ 3 웅, Madden Dam, 8 July I950, $0^{\star}$, Miraflores Locks, 3 July 1958, O , Pédro Miguel, 3 1 Dec. 1957, \& (AMC); Summit, Jan. 1947, $\sigma^{\pi}$ (NLHK), 7-IO July 1950, $0^{\pi}+$, 2 I-29 July 1950, $40^{x} 0^{x}: 3$ 우우, 16-I7 Aug. I950, 30 $0^{x}:$ 우, 23-28 Aug. I950, $30^{\pi} 0^{\pi}:$ 우우, 17 Aug. 1954, ㅇ (AMC).

\section{Oxyopes bifissus F.O.P.-Cambridge}

Figures 3, 4, 37, 38, 57-60, 84-89. Map I.

Oxyopes bifissus F.O.P.-Cambridge, 1902, Biologia Centrali-Americana, Arachnida, Araneidea, 2:344, pl. 32, figs. 21, 21a, 22, 수 ㅇ․ Male holotype from Teapa, Tabasco, Mexico, in British Museum (Natural History), examined. Roewer, 1954, Katalog der Araneae, 2(a) :331. Bonnet, 1958, Bibliographia Araneorum, 2(4) :3225.

Oxyopes calcarifer F.O.P.-Cambridge, 1902, Biologia Centrali-Americana, Arachnida, Araneidea, $2: 344$, pl. 32. fig. 24, $\hat{o}$. Male holotype from Costa Rica, in British Museum (Natural History), examined. NEW SYNONYMY.

Discussion. Oxyopes calcarifer F.O.P.-Cambridge is undoubtedly the same species as $O$. bifissus as evidenced by a comparison of the male holotypes (compare Figs. 84,85 with Figs. 86,87 ).

Figs. 1-2. Oxyopes bifidus F.O.P.-Cambridge, female from Compostela, Nayarit, 12 July 1972. 1. Face view. 2. Dorsal view.

Figs. 3-4. Oxyopes bifissus F.O.P.-Cambridge, female from Tamazunchale, San Luis Potosi, 19 April 1963. 3. Face view. 4. Dorsal view.

Figs. 5-6. Oxyopes tibialis F.O.P.-Cambridge, female from Musawas on Waspuc River, Nicaragua, 10-31 Oct. 1955. 5. Face view. 6. Dorsal view.

Figs. 7-8. Oxyopes chiapas new species, female from La Zacualpa, Chiapas, Aug. 1909. 7. Face view. 8. Dorsal view.

Figs, 9-10. Oxyopes summus new species, female from Gamboa, Panama Canal Zone, 24 July 1959. 9. Face view. 10. Dorsal view.

Figs. 11-12. Oxyopes salticus Hentz, female from Horsetail Falls, Nuevo Leon, 7 July 1972. 11. Face view. 12. Dorsal view. 
Measurements. Ten females and ten males.

\begin{tabular}{|c|c|c|c|c|c|}
\hline FEMALES: & Mean & Range & & Mean & Range \\
\hline Clypeus & .463 & $.40-.55$ & Femur I & 2.21 & $2.0-2.4$ \\
\hline AME & .363 & $.33-.43$ & Patella-Tibia I & 2.70 & $2.4-2.9$ \\
\hline ALE & .673 & $.63-.75$ & Metatarsus I & 2.18 & $2.0-2.4$ \\
\hline PLE & 1.223 & $1.10-1.38$ & Tarsus I & .91 & $.8-1.0$ \\
\hline PME & .680 & $.60-.78$ & Total Length I & 8.00 & $7.3-8.6$ \\
\hline $\begin{array}{l}\text { Carapace } \\
\text { Width }\end{array}$ & 1.77 & $1.5-2.0$ & & & \\
\hline $\begin{array}{l}\text { Carapace } \\
\text { Length }\end{array}$ & 2.31 & $2.0-2.6$ & $\begin{array}{l}\text { Patella-Tibia II } \\
\text { Patella-Tibia III }\end{array}$ & $\begin{array}{l}2.56 \\
2.05\end{array}$ & $\begin{array}{l}2.3-2.8 \\
1.9-2.3\end{array}$ \\
\hline $\begin{array}{l}\text { Total } \\
\text { Length }\end{array}$ & 5.27 & $3.9-6.5$ & $\begin{array}{l}\text { Patella-Tibia IV } \\
\text { Total Length IV }\end{array}$ & $\begin{array}{l}2.24 \\
7.37\end{array}$ & $\begin{array}{l}2.1-2.5 \\
6.5-8.1\end{array}$ \\
\hline MALES: & Mean & Range & & Mean & Range \\
\hline Clypeus & .335 & $.28-.45$ & Femur I & 2.06 & $1.9-2.4$ \\
\hline AME & .320 & $.30-.40$ & Patella-Tibia I & 2.64 & $2.4-3.0$ \\
\hline ALE & .590 & $.55-.70$ & Metatarsus I & 2.40 & $2.2-2.8$ \\
\hline PLE & 1.063 & $.95-1.30$ & Tarsus I & 1.10 & $.9-1.3$ \\
\hline PME & .590 & $.55-.70$ & Total Length I & 8.19 & 7.4-9.4 \\
\hline $\begin{array}{l}\text { Carapace } \\
\text { Width }\end{array}$ & 1.61 & $1.5-1.9$ & Patella-Tibia II & 2.44 & $2.2-2.8$ \\
\hline $\begin{array}{l}\text { Carapace } \\
\text { Length }\end{array}$ & 2.09 & $1.9-2.5$ & Patella-Tibia III & 1.88 & $1.7-2.2$ \\
\hline $\begin{array}{l}\text { Total } \\
\text { Length }\end{array}$ & 4.20 & $3.7-5.3$ & $\begin{array}{l}\text { Patella-Tibia IV } \\
\text { Total Length IV }\end{array}$ & $\begin{array}{l}2.05 \\
6.98\end{array}$ & $\begin{array}{l}1.8-2.4 \\
6.2-8.0\end{array}$ \\
\hline
\end{tabular}

Color. Female. Face and chelicerae yellow to pale orange with darker brownish or black stripes as illustrated in Figure 3. Eyes surrounded with black, overlaid with white spatulate-shaped hair. Lower edge of clypeus white to pale cream.

Carapace yellow to pale orange with dark brown hairs forming pattern as illustrated in Figure 4.

Dorsum of abdomen white to pale yellow, bordered by dark brown as in Figure 4. Venter white to pale yellow, speckled with brown.

Legs yellow to pale orange with irregular dusky spots, most conspicuous ventrally.

Labium cream to pale orange. Endites cream to pale orange, outlined with dark brown, Sternum white to pale yellow, with dark brown margin. 
Color. Males of $O$. bifissus occur in two color phases. The darker of these forms is described first, then the lighter phase.

Dark male. Face and chelicerae dark brown with vertical black stripes as in Figure 57. Eye region dark brown with iridescent scales. Cymbia of palpi dark brown to black. Distal ends of chelicerae lighter.

Carapace with median area light brown, bordered by dark brown to black as shown in Figure 58.

Dorsum of abdomen light brown in center to dark brown along sides as in Figure 58; overlaid with iridescent scales. Spinnerets yellow to light orange-brown. Venter dark brown to black with pale lines originating at corners of epigastric furrow and continuing to base of spinnerets. Median area heavily clothed with iridescent scales. Scales impart a green or pink iridescence in preserved specimens.

Legs yellow to light orange-brown. Longitudinal black line along retrolateral surface of femora I.

Labium and endites dark brown to black with pale distal ends. Sternum brown.

Light male. Face and chelicerae orange-brown with vertical black stripes as indicated in Figure 59. Distal ends of chelicerae pale yellow. Eye region with a few iridescent scales. Cymbia of palpi dark brown.

Carapace light orange-brown, darker along sides as shown in Figure 60 .

Dorsum of abdomen white to pale cream, overlaid with iridescent scales, bounded by darker brown as in Figure 6o. Spinnerets orangeyellow. Venter white to pale cream spotted with brown.

Legs cream to pale yellow.

Labium and endites pale yellow-orange. Sternum pale yellow.

Diagnosis. Oxyopes bifissus is similar to O. bifidus in form and coloration. The male palpi of these two species are much alike, but distinct (compare Figs. 84-89 with Figs. 78-8I). The two species can be readily distinguished by their epigyna (compare Figs. 37, 38 with Figs. 25-30).

Distribution. Eastern Mexico to Costa Rica (Map I).

Records. MEXICO. San Luis Potosí. Tamazunchale, I9 Apr. 1963, ot o 우 (WJG, WI). Veracruz. La Buena Ventura, July I909, 우 (AP). Oaxaca. Palomares, July 1909, $120^{x} 0^{x}: 5$ 우 + : 500 (AP). Chiapas. Pichucalco, I7 July 1947, $0^{7}+{ }^{\circ}$ (CG, MG). Tabasco. Teapa, $0^{7}+9$ (HHS), I6 July 1947, $0^{7}+9$ (CG, MG). COSTA RICA. $0^{\pi}$ (Rogers). 


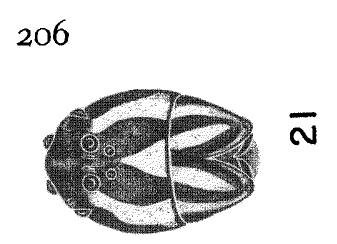

$$
\text { Psyche }
$$

[June
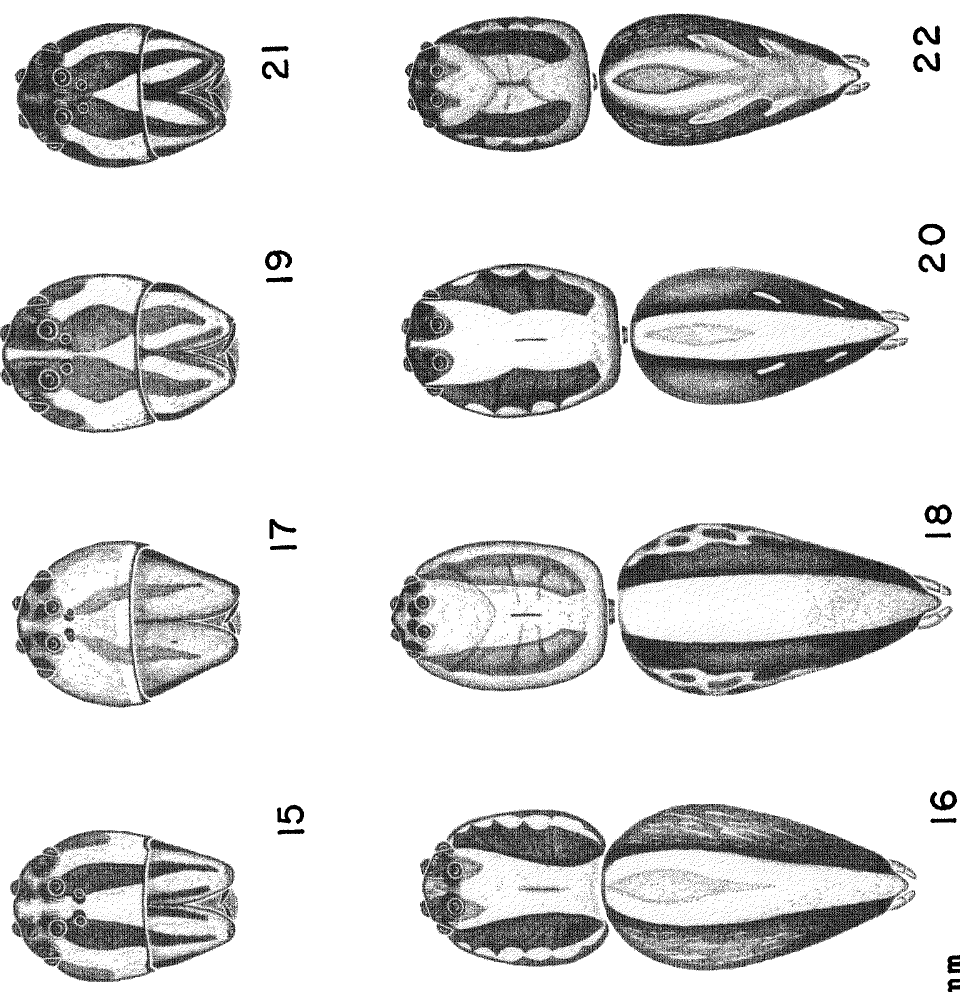

느
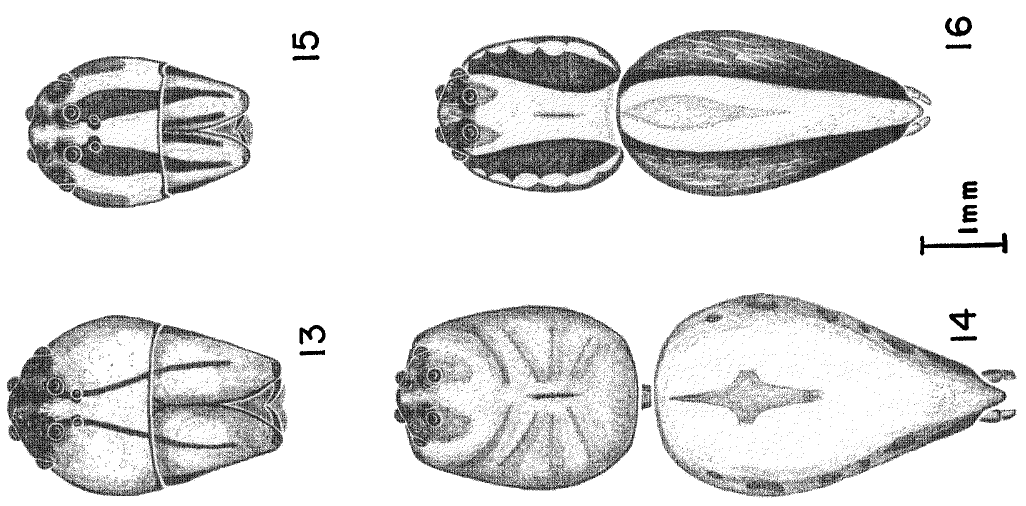
Oxyopes tibialis F.O.P.-Cambridge

Figures 5, 6, 35, 36, 61, 62, 94-97. Map I.

Oxyopes tibialis F.O.P.-Cambridge, 1902, Biologia Centrali-Americana, Arachnida, Araneidea, 2:344, pl. 32, figs. 23, 23a, ̂. Male holotype from Guatemala, in British Museum (Natural History), examined.

Oxyopes transversus F.O.P.-Cambridge, 1902, Biologia Centrali-Americana, Arachnida, Araneidea, 2:345, pl. 32, fig. 28, ㅇ. Female holotype from Teapa, Tabasco, Mexico, in British Museum (Natural History), examined. NEW SYNONYMY.

Discussion. Oxyopes transversus of F.O.P.-Cambridge ( I902) is almost certainly the female of $O$. tibialis. Collections from four different localities contain representatives of both sexes taken together. Size, coloration, and morphological features lend support to this synonymy.

Measurements. Ten females and ten males.

\begin{tabular}{|c|c|c|c|c|c|}
\hline FEMALES: & Mean & Range & & Mean & Range \\
\hline Clypeus & .503 & $.48-.55$ & Femur I & 2.32 & $2.1-2.6$ \\
\hline AME & .325 & $.30-.38$ & Patella-Tibia I & 2.80 & $2.5-3.2$ \\
\hline ALE & .628 & $.60-.68$ & Metatarsus I & 2.30 & $2.0-2.6$ \\
\hline PLE & 1.120 & $1.05-1.20$ & Tarsus I & .92 & $0.9-1.0$ \\
\hline PME & .623 & $.60-.68$ & Total Length I & 8.33 & $7.4-9.3$ \\
\hline $\begin{array}{l}\text { Carapace } \\
\text { Width }\end{array}$ & 1.75 & $1.7-2.0$ & & & \\
\hline $\begin{array}{l}\text { Carapace } \\
\text { Length }\end{array}$ & 2.32 & $2.2-2.6$ & $\begin{array}{l}\text { Patella-Tibia II } \\
\text { Patella-Tibia III }\end{array}$ & $\begin{array}{l}2.60 \\
1.99\end{array}$ & $\begin{array}{l}2.3-3.0 \\
1.8-2.3\end{array}$ \\
\hline $\begin{array}{l}\text { Total } \\
\text { Length }\end{array}$ & 5.62 & $4.6-6.4$ & $\begin{array}{l}\text { Patella-Tibia IV } \\
\text { Total Length IV }\end{array}$ & $\begin{array}{l}2.26 \\
7.52\end{array}$ & $\begin{array}{l}2.0-2.6 \\
6.7-8.6\end{array}$ \\
\hline
\end{tabular}

Figs. 13-14. Oxyopes flavus Banks, female from Iquala, Guerrero, 27 Oct. 1947. 13. Face view. 14. Dorsal view.

Figs. 15-16. Oxyopes panther new species, female from Palos Colorados, Durango, 5 Aug. 1947. 15. Face view. 16. Dorsal view.

Figs. 17-18. Oxyopes ocelot new species, female from Arcelia, Guerrero, 2 Nov. 1947. 17. Face view. 18. Dorsal view.

Figs, 19-20. Oxyopes cornutus F.O.P.-Cambridge, female from $8 \mathrm{mi}$. SW of Colima, Colima, 10 May 1963. 19. Face view. 20. Dorsal view.

Figs. 21-22. Oxyopes felinus Brady, female from SW of Acaponeta, Nayarit, 15 May 1963. 21. Face view. 22. Dorsal view. 


\begin{tabular}{|c|c|c|c|c|c|}
\hline MALES: & Mean & Range & & Mean & Range \\
\hline Clypeus & .445 & $.38-.50$ & Femur I & 2.24 & $2.1-2.4$ \\
\hline AME & .313 & $.30-.33$ & Patella-Tibia I & 2.87 & $2.6-3.2$ \\
\hline ALE & .583 & $.55-.65$ & Metatarsus I & 2.58 & $2.4-2.8$ \\
\hline PLE & 1.043 & $.98-1.13$ & Tarsus I & 1.18 & $1.1-1.3$ \\
\hline PME & .583 & $.55-.65$ & Total Length I & 8.86 & $8.0-9.5$ \\
\hline $\begin{array}{l}\text { Carapace } \\
\text { Width }\end{array}$ & 1.69 & $1.6-1.8$ & & & \\
\hline $\begin{array}{l}\text { Carapace } \\
\text { Length }\end{array}$ & 2.19 & $2.0-2.3$ & $\begin{array}{l}\text { Patella-Tibia II } \\
\text { Patella-Tibia III }\end{array}$ & $\begin{array}{l}2.58 \\
1.93\end{array}$ & $\begin{array}{l}2.3-2.8 \\
1.6-2.1\end{array}$ \\
\hline Total & & & Patella-Tibia IV & 2.16 & $2.0-2.4$ \\
\hline Length & 4.63 & $4.1-5.0$ & Total Length IV & 7.30 & $6.6-7.9$ \\
\hline
\end{tabular}

Color. Female. Face and chelicerae pale yellow to light yelloworange with dark stripes from AME to subdistal region of chelicerae as in Figure 5. Eyes with black nacelles, overlaid with white spatulate hair.

Carapace cream to light yellow-orange, with broad dark submarginal stripes as in Figure 6.

Dorsum of abdomen with cardiac area translucent, accented by white. Median area white to pale yellow, outlined by mottled brownish yellow anteriorly and dark brown posteriorly as in Figure 6. Spinnerets pale yellow. Venter with broad, mottled brown or solid brown median stripe from epigastric furrow to base of spinnerets.

Legs yellow. Femora I-III with mid-ventral dark lines.

Labium and endites yellow to light yellow-orange. Sternum cream to pale yellow.

Color. Male. Face and chelicerae with black reticulate pattern and indistinct vertical stripes as in Figure 6r. Some specimens dark brown to black without stripes apparent. Cymbia of palpi black. Eyes with black nacelles.

Carapace yellow to yellow-orange in some; dark brown with lighter yellow surrounding thoracic groove in others.

Dorsum of abdomen brown mottled with cream to yellow, giving overall gray-brown appearance. Spinnerets yellow. Venter with same mottled appearance as dorsum, with a wide median brown stripe from epigastric furrow to base of spinnerets.

Legs yellow with median ventral stripe on femora I-III.

Labium brown with light yellow distal end. Endites brown with light yellow inner margins and distal ends. Sternum yellow. 

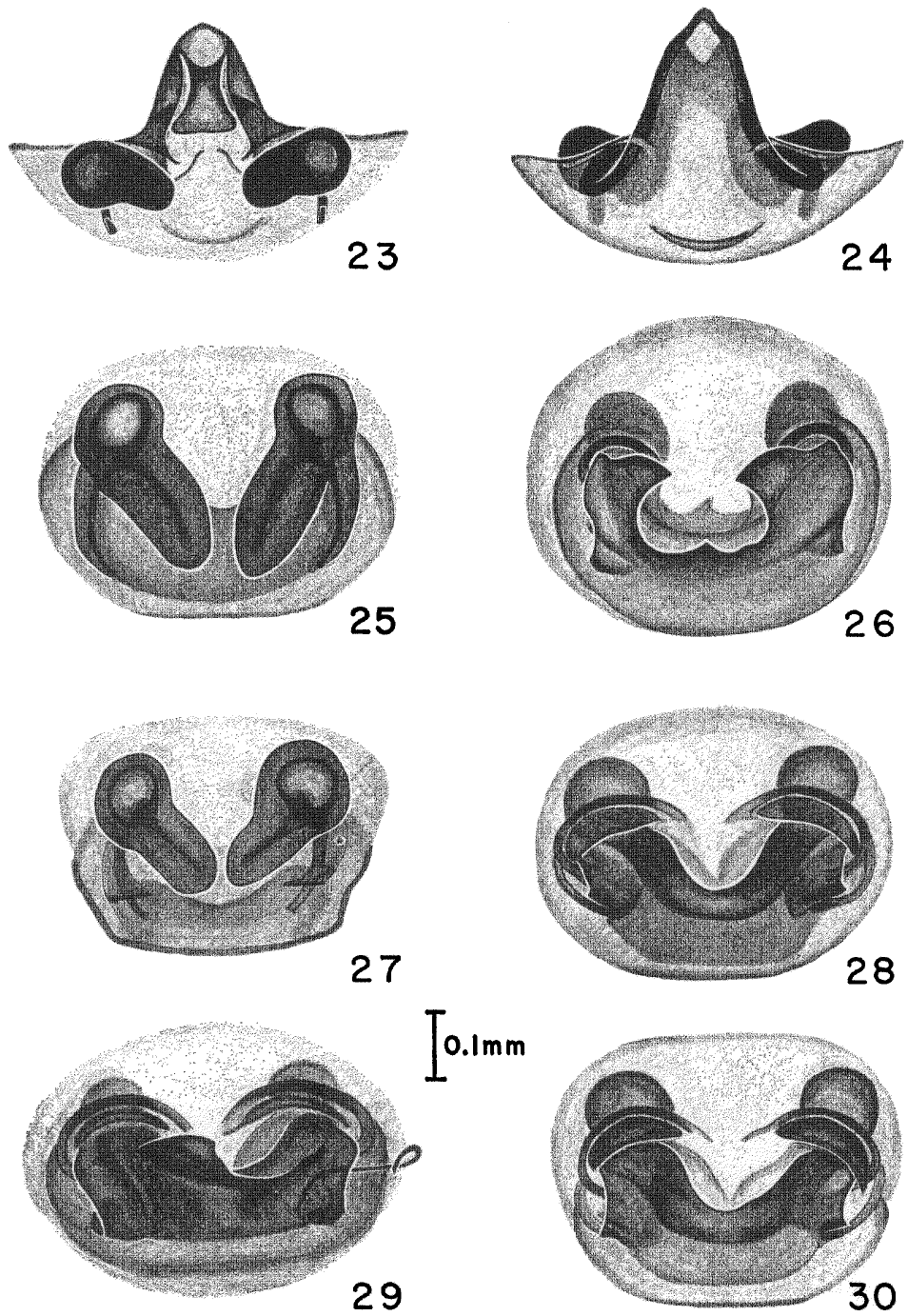

Figs. 23-24. Oxyopes salticus Hentz, female from Horsetail Falls, Nuevo Leon, 7 July 1972. 23. Internal genitalia. 24. Epigynum.

Figs. 25-26. Oxyopes bifidus F.O.P.-Cambridge, female from Compostela, Nayarit, 12 July 1972. 25. Internal genitalia. 26. Epigynum.

Figs. 27-30. Oxyopes bifidus F.O.P.-Cambridge, females from Rio de las Flores, Chiapas, 15 Sept. 1947. 27. Internal genitalia. 28-30. Epigyna. 
Diagnosis. Oxyopes tibialis is closest to O. acleistus as it is understood in this paper. Color patterns of these two species are alike (compare Figs. 5, 6 to figs. I-6 of Brady, I964), and the male and female reproductive organs are similar. The two species can be distinguished by comparing the epigynum of $O$. tibialis (Figs. 35, 36) to that of $O$. acleistus (figs. $13-20$ of Brady, 1964). In males, the tibial apophysis of $O$. tibialis (Figs. 94-97) is larger than that of $O$. acleistus (figs. 35-38 of Brady, I964) and their palpal sclerites differ.

Distribution. Southern Mexico and Central America (Map I).

Records. MEXICO. Veracruz, Tuxtilla, 23 July 1946, $\sigma^{\top}$ (HMW). Tabasco. Teapa, 4우우 :o (HHS). Campeche. San Jose, Dec. I946, o (HMW). Yucatan. Colonia Yucatan, I3-I9 Aug. 1952, 우 우 (JP, DP).

GUATEMALA. Los Amates, I908, $4 \sigma^{\star} \sigma^{\star}:$ : $+: 300$ (Kellerman), Panzos, I4-I7 July 1947, \& (CV, PV).

HONDURAS. La Ceiba, I9 Dec. I9r6, ㅇ (Dyer) ; Lancetilla, July I929, $\sigma^{\pi}: 3 ㅇ ㅜ$, Progress, 6 July ig29, $\sigma^{\star}$, Tela, 26 July I929, $30^{x} 0^{x}: 5$ 우 (AMC).

NICARAGUA. Musawas, Waspuc River, 30 Sept. 1955, 0َ, IO-3I Oct. I955, $q$ (BM).

\section{Oxyopes chiapas new species}

Figures 7, 8, 33, 34, 63, 64, 92, 93. Map I.

Holotype. Male from La Zacualpa, Chiapas, Mexico, Aug. I909, (A. Petrunkevitch), in American Museum of Natural History. The specific name is a noun in apposition after the type locality.

Measurements. Five females and two males.

\begin{tabular}{|c|c|c|c|c|c|}
\hline FEMALES: & Mean & Range & & Mean & Range \\
\hline Clypeus & .475 & $.43-.50$ & Femur I & 2.19 & $2.0-2.3$ \\
\hline AME & .305 & $.30-.33$ & Patella-Tibia I & 2.72 & $2.6-2.8$ \\
\hline ALE & .600 & $.58-.63$ & Metatarsus I & 2.26 & $2.2-2.3$ \\
\hline PLE & 1.075 & $1.05-1.13$ & Tarsus I & .88 & .9 \\
\hline PME & .600 & $.58-.63$ & Total Length I & 8.06 & $7.8-8.3$ \\
\hline $\begin{array}{l}\text { Carapace } \\
\text { Width }\end{array}$ & 1.63 & $1.6-1.7$ & & & \\
\hline $\begin{array}{l}\text { Carapace } \\
\text { Length }\end{array}$ & 2.22 & $2.1-2.3$ & $\begin{array}{l}\text { Patella-Tibia II } \\
\text { Patella-Tibia III }\end{array}$ & $\begin{array}{l}2.50 \\
1.93\end{array}$ & $\begin{array}{l}2.4-2.6 \\
1.9-2.0\end{array}$ \\
\hline $\begin{array}{l}\text { Total } \\
\text { Length } \\
\end{array}$ & 5.19 & $5.0-5.4$ & $\begin{array}{l}\text { Patella-Tibia IV } \\
\text { Total Length IV }\end{array}$ & $\begin{array}{l}2.18 \\
7.31\end{array}$ & $\begin{array}{l}2.1-2.3 \\
7.0-7.6\end{array}$ \\
\hline
\end{tabular}


MALES:

\begin{tabular}{ll|ll}
\hline Clypeus & $.40, .43$ & Femur I & $2.0,2.3$ \\
AME & $.30, .30$ & Patella-Tibia I & $2.6,2.8$ \\
ALE & $.55, .55$ & Metatarsus I & $2.5,2.7$ \\
PLE & $.98,1.00$ & Tarsus I & $1.1,1.2$ \\
PME & $.55, .55$ & Total Length I & $8.2,9.0$ \\
Carapace & & & \\
Width & $1.5,1.6$ & & \\
Carapace & & Patella-Tibia II & $2.4,2.7$ \\
Length & $2.0,2.1$ & Patella-Tibia III & $1.8,2.0$ \\
Total & & Patella-Tibia IV & $2.0,2.3$ \\
Length & $4.1,4.3$ & Total Length IV &,- 7.7 \\
\hline
\end{tabular}

Color. Female. Face and chelicerae pale cream to yellow with vertical black stripes from AME to subdistal ends of chelicerae as in Figure 7. Eye nacelles black, overlaid with white hair.

Carapace pale yellow.

Dorsum of abdomen white to cream with brown along sides as in Figure 8. Spinnerets pale yellow. Venter with broad cream colored stripe outlined with brown, extending from epigastric furrow to base of spinnerets. Lateral areas white.

Legs cream to pale yellow. Brown stripe on ventral surface of femora $I$ and II in one specimen.

Labium brown. Endites pale yellow. Sternum cream.

Color. Male. Face and chelicerae pale yellow to yellow-orange. Black vertical stripes from AME to subdistal region of chelicerae as in Figure 63. Eye region black. Iridescent spatulate hairs between PME. Cymbia of palpi dark brown to black.

Carapace yellow to yellow-orange. Some purplish iridescence in one male.

Dorsum of abdomen with cardiac area translucent gray, surrounded by white pigment with lateral areas dark brown to black as in Figure 64. Other male with dorsum entirely black. Venter with dark patch over genital area. Dark median stripe from epigastric furrow to base of spinnerets. Spinnerets yellow. Other male with venter entirely black.

Legs yellow. Faint stripe on ventral surface of femur $I$ in one male. 

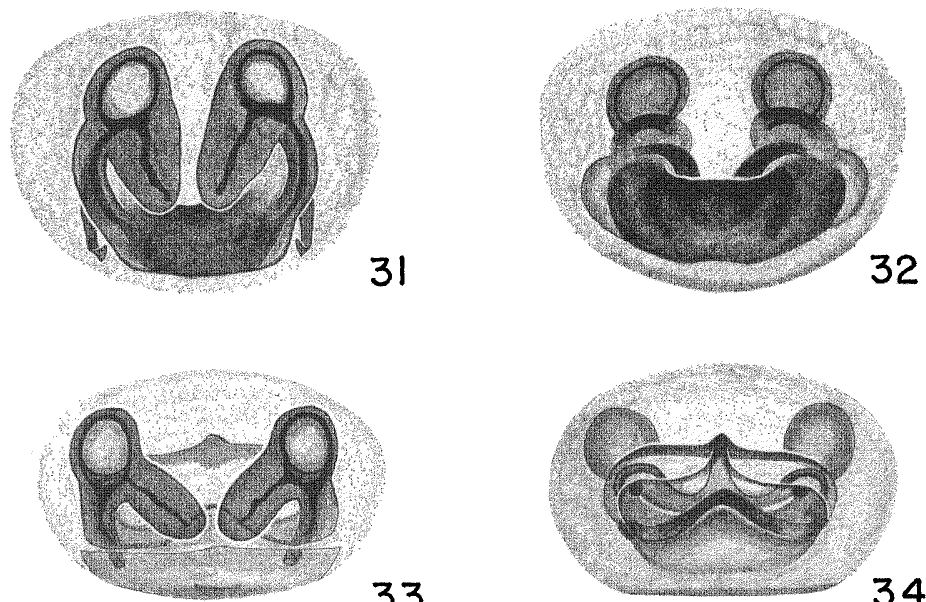

33
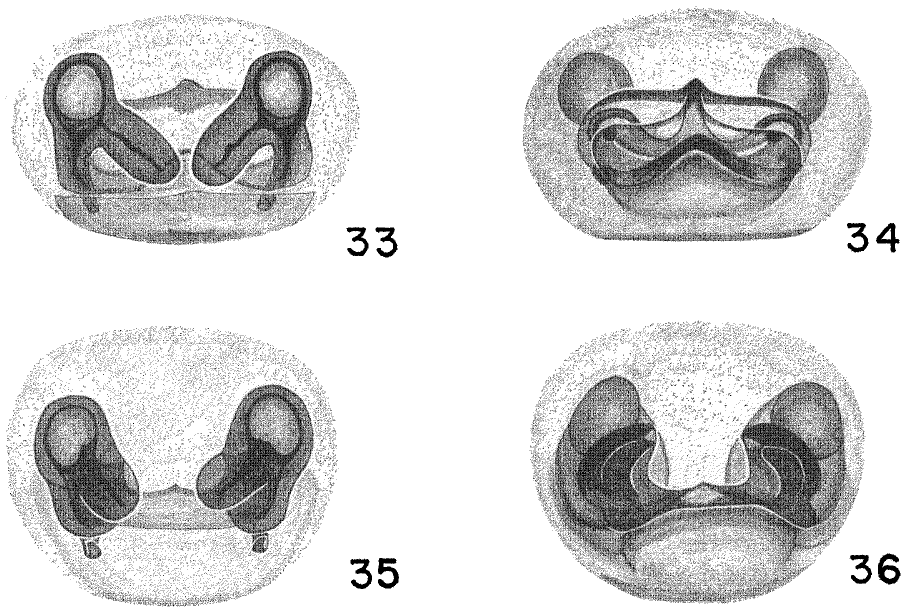

35
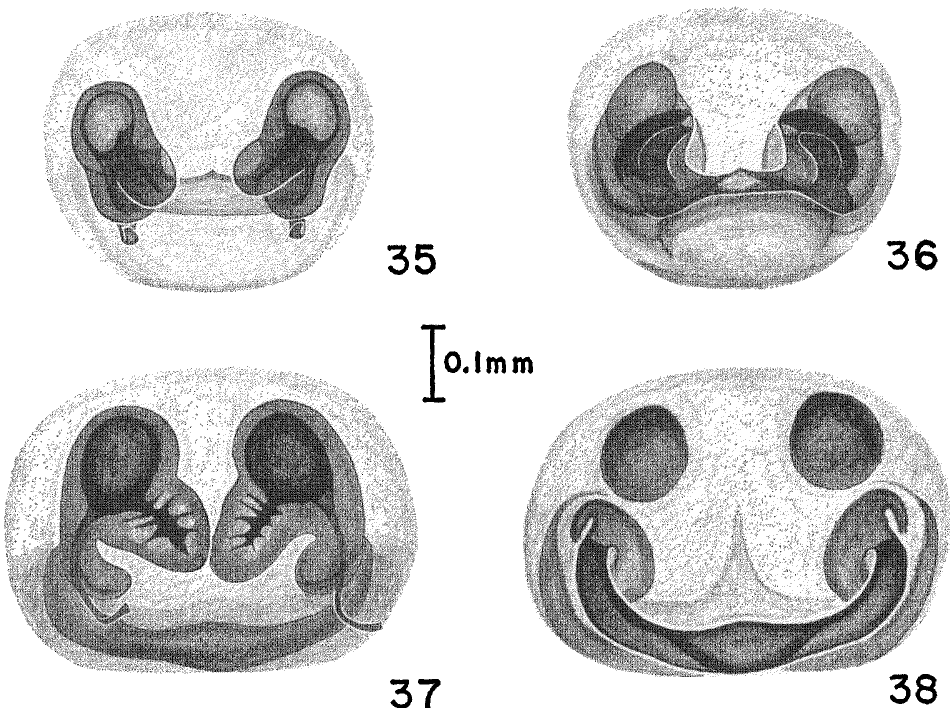

$\lceil 0.1 \mathrm{~mm}$

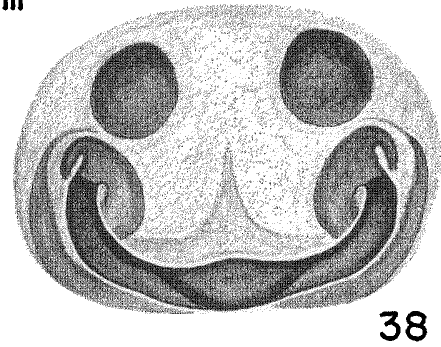


Labium and endites yellow to yellow-orange. Sternum yellow.

Diagnosis. Oxyopes chiapas is related to other members of the acleistus species group based upon its color pattern and genital structure. It is probably closest to $O$. summus, but is easily distinguished from this species and all others by the structure of the female genitalia (Figs. 33, 34) and the male palpus (Figs. 92, 93).

Record. MEXICO. Chiapas. La Zacualpa, Aug. 1909, $0^{x} \sigma^{x}$ : 5 우우: 00 (AP).

\section{Oxyopes summus new species}

Figures 9, 10, 31, 32, 65, 66, 90, 91. Map I.

Holotype. Male from Summit, Panama Canal Zone, 2I-29 July 1950, (A.M. Chickering), in Museum of Comparative Zoology. The specific name is a noun in apposition after the type locality.

Measurements. Seven females and four males.

\begin{tabular}{lcc|lcc} 
FEMALES: & Mean & \multicolumn{1}{c}{ Range } & & Mean & Range \\
\hline Clypeus & .440 & $.43-.48$ & Femur I & 1.96 & $1.8-2.1$ \\
AME & .310 & $.30-.33$ & Patella-Tibia I & 2.44 & $2.3-2.6$ \\
ALE & .608 & $.58-.63$ & Metatarsus I & 1.96 & $1.8-2.1$ \\
PLE & 1.065 & $1.03-1.13$ & Tarsus I & .80 & $.7-.9$ \\
PME & .578 & $.55-.60$ & Total Length I & 7.16 & $6.7-7.7$ \\
Carapace & & & & & \\
Width & 1.56 & $1.4-1.7$ & Patella-Tibia II & 2.24 & $2.1-2.4$ \\
$\begin{array}{l}\text { Carapace } \\
\text { Length }\end{array}$ & 2.09 & $1.9-2.2$ & Patella-Tibia III & 1.68 & $1.6-1.8$ \\
$\begin{array}{l}\text { Total } \\
\text { Length }\end{array}$ & 4.87 & $4.2-5.5$ & Patella-Tibia IV & 1.97 & $1.8-2.1$ \\
\hline
\end{tabular}

Figs. 31-32. Oxyopes summus new species, female from Gamboa, Panama Canal Zone, 24 July 1954. 31. Internal genitalia. 32. Epigynum.

Figs. 33-34. Oxyopes chiapas new species, female from La Zacualpa, Chiapas, Aug. 1909. 33. Internal genitalia. 34. Epigynum.

Figs. 35-36. Oxyopes tibialis F.O.P.-Cambridge, female from Musawas on Waspuc River, Nicaragua, 10-31 Oct. 1955. 35. Internal genitalia. 36. Epigynum.

Figs. 37-38. Oxyopes bifissus F.O.P.-Cambridge, female from Tamazunchale, San Luis Potosi, 19 April 1963. 37. Internal genitalia. 38. Epigynum. 


\begin{tabular}{ll|lc} 
MALES: & \multicolumn{2}{l}{ Range } & Range \\
\hline Clypeus & $.30-.38$ & Femur I & $1.7-2.0$ \\
AME & $.28-.30$ & Patella-Tibia I & $2.2-2.7$ \\
ALE & $.50-.55$ & Metatarsus I & $2.0-2.4$ \\
PLE & $.90-1.00$ & Tarsus I & $.8-.9$ \\
PME & $.50-.55$ & Total Length I & $6.8-8.0$ \\
Carapace & & & \\
Width & $1.3-1.6$ & & \\
Carapace & & Patella-Tibia II & $2.0-2.4$ \\
Length & $1.7-2.1$ & Patella-Tibia III & $1.4-1.7$ \\
Total & & Patella-Tibia IV & $1.6-2.0$ \\
Length & $3.5-4.2$ & Total Length IV & $5.6-6.7$ \\
\hline
\end{tabular}

Color. Female. Face and chelicerae pale orange-yellow, lighter cream along lower edge of clypeus. A pair of black lines from AME to subdistal region of chelicerae as in Figure 9. Eye nacelles black.

Carapace pale orange-yellow with darker brown submarginal stripes as in Figure Io.

Dorsum of abdomen with a broad median white stripe from base to spinnerets, outlined with dark brown. Sides mottled with brown as in Figure ro.

Venter with a broad median black stripe from epigastric furrow to base of spinnerets, mottled with cream in center. Median stripe flanked by pale cream.

Legs yellow with mid-ventral black line on femora I and II. Line faintly visible on femora III.

Labium and endites cream to pale yellow with lighter distal ends. Sternum ivory to cream.

Color. Male. Face and chelicerae pale orange-yellow; lighter along lower edge of clypeus. 'Two black lines from AME to subdistal end of chelicerae as in Figure 65. Eye tubercles black.

Carapace pale orange-yellow with few scattered dusky hairs. Faint iridescent sheen of green and purple.

Dorsum of abdomen with a broad white stripe from base to tips of spinnerets, bordered laterally by mottled light brown extending along sides as in Figure 66.

Venter with wide black median stripe from genital area to base of spinnerets, bounded by pale yellow.

Legs yellow with mid-ventral black stripe on femora I-III.

Labium pale yellow with brownish tinge. Endites pale yellow. Sternum cream.

Diagnosis. Oxyopes summus is placed in the acleistus species group because of its leg formula of I-II IV-III. Although its dorsal 

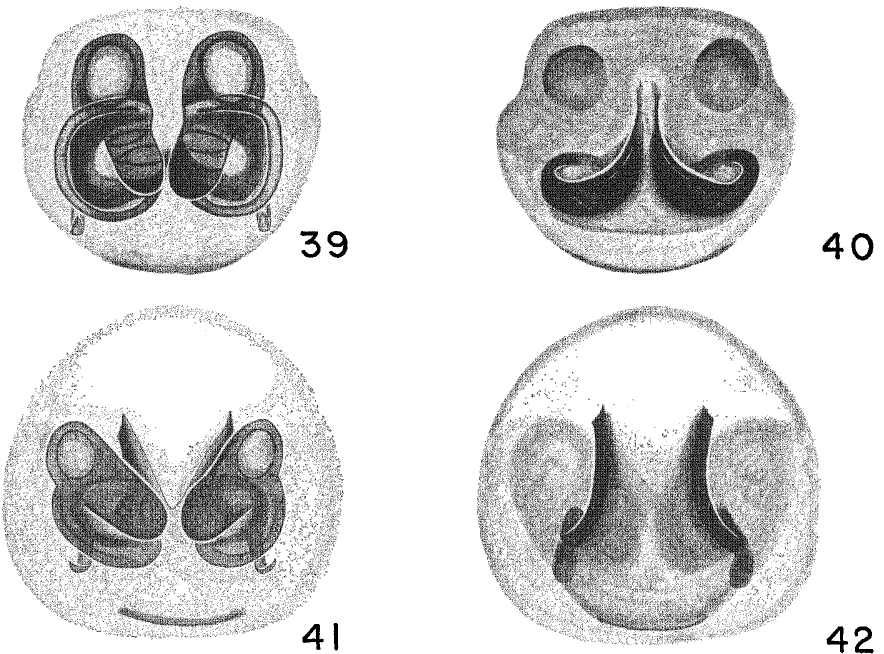

42
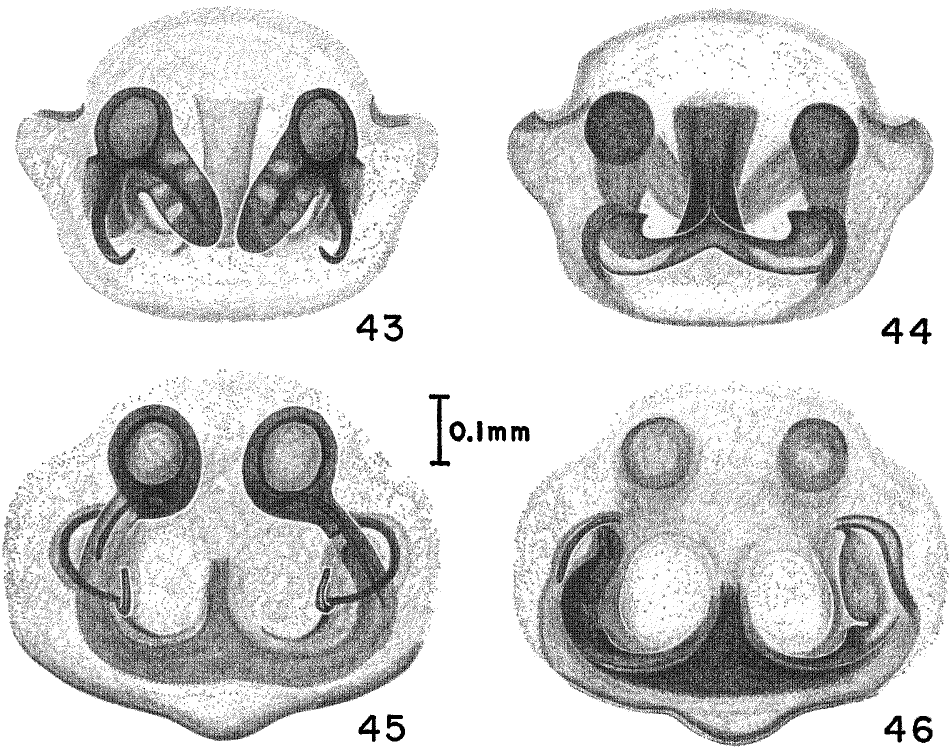

Figs. 39-40. Oxyopes felinus Brady, female from SW of Acaponeta, Nayarit, 15 May 1965. 39. Internal genitalia. 40. Epigynum.

Figs. 41-42. Oxyopes ocelot new species, female for Arcelia, Guerrero, 2 Nov. 1974. 41. Internal genitalia. 42. Epigynum.

Figs. 43-44. Oxyopes cornutus F.O.P.-Cambridge, female from $8 \mathrm{mi}$. SW of Colima, Colima, 10 May 1963. 43. Internal genitalia. 44. Epigynum.

Figs. 45-46. Oxyopes panther new species, female from Palos Colorados, $25 \mathrm{mi}$. W of Durango, 5 Aug. 1947. 45. Internal genitalia. 46. Epigynum. 
color pattern is like some members of the tridens group, the stripes on the face are more like the acleistus group. Finally the epigynum (Figs. 3I, 32) and male palpus (Figs. 90, 9I) are similar to members of the acleistus group (O. chiapas, for example), but these reproductive organs readily separate summus from related species. Its color pattern is also distinctive for the acleistus group.

Natural History. All of the specimens of O. summus collected by Chickering were included in the same vials with specimens of O. salticus. Oxyopes salticus were much more numerous. Presumably $O$. summus occurs in the same or an adjacent habitat.

Distribution. Costa Rica and Panama.

Records. COSTA RICA. Guanacaste. La Irma, 5 Aug. 1973, o , (ARB, RJW).

PANAMA. Canal Zone. Naval Air Station near Cocoli, I3 Jan. 1958, \&, Gamboa, 24 July 1952, 우, i July i958, 우, 2 mi. $\mathbf{N}$ of Paraiso, 2 I Jan. 1958, $q$, Pédro Miguel, 31 Dec. 1957, $0^{7} \sigma^{7}+$, Summit, 21-29 July 1950, 우, 23-28 Aug. 1950, $0^{\pi}: 3$ 우 (AMC).

\section{Oxyopes apollo Brady Map 2.}

Oxyopes apollo Brady, 1964, Bull. Mus. Comp. Zool., 131(13) :467, figs. 41, 42, 47-50, 72-75, $\hat{o}$ ㅇ. Male holotype from Encino, Brooks Co., Texas, in the American Museum of Natural History. Brady, 1969, Psyche, $76(4): 428$.

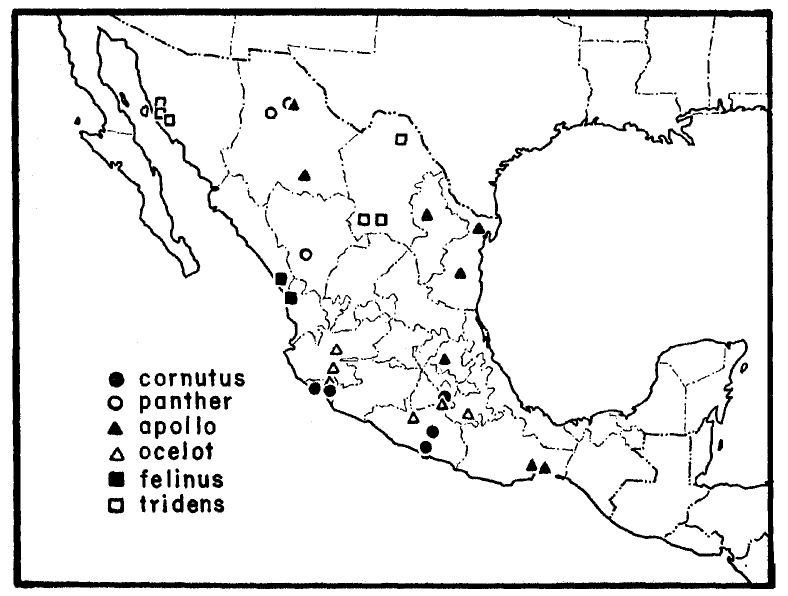

Map 2. 
Discussion. Oxyopes floridanus of Brady, 1964 was recognized as the same species as $O$. apollo in a review of the apollo species group (Brady, 1969). The reasons for synonymy are discussed in that paper.

For illustrations, measurements, color descriptions, diagnoses, notes on natural history, and collection records north of Mexico, see Brady (I964), pages 467-47 I and Brady (1969), pages 428-43I.

Distribution. Tennessee, Missouri, Arkansas, south through Oklahoma and Texas, west to Arizona and south through Nuevo Leon and Chihuahua to Oaxaca.

Records. MEXICO. Tamaulipas. San Pedro, May 1936, $0^{\pi}$ : 8 우우 (W. A. Green), Santa Teresa, I5 May I952, 3 우우:o (MAC, WJG, RS). Nuevo Leon. N of Monterey, 8 Aug. 1942, $\sigma^{*}$. Chihuahua. $50 \mathrm{mi}$. S of Villa Ahumada, II June 1939, $0^{7}$ 우 0 (AMD, LID). Hidalgo. Io mi. $\mathrm{N}$ of Ixmiquilipan, 5 July I94I, $0^{\pi}$ (AMD). Oaxaca. Jalapa, 28 Aug. 1947, 0, Tuchitan, 30 Aug. I947, $0^{x} o^{x}: 9$ 우우 :o ( $\mathrm{HMW}$ ).

\section{Oxyopes tridens Brady \\ Map 2.}

Oxyopes tridens Brady, 1964, Bull. Mus. Comp. Zool., 131(13) :472, figs. 45, 46, 53-55, 62, 63, 70, 71, ㅎํ. Male holotype from Mercury, Nye Co., Nevada, in the American Museum of Natural History.

Discussion. For illustrations, measurements, color description, diagnosis, notes on natural history, and collection records north of Mexico, see Brady (1964), pages 472-474.

Records. MEXICO. Coahuila. La Gloria, 24 Aug. 1947, 우 (WJG) ; 20 mi. E of San de las Colonias, 5 July I936, 우 (AMD, LID). Chihuahua. Samalayuca, 25 June 1947, $\sigma^{*}$ (WJG). Sonora. El Desemboque, I-IO Sept. I953, $0^{x}, 25 \mathrm{~km} \mathrm{~S}$ of El Desemboque, i I Aug. 1953, ㅇ (BM); ro mi. S of Hermosillo, I6 June 1939, q (AMD, LID).

\section{Oxyopes felinus Brady}

Figures 21, 22, 39, 40, 69, 70, 102, 103. Map 2.

Oxyopes felinus Brady, Bull. Mus. Comp. Zool., 131(13):476, figs. 56, 57, 64, 65, ․․ Male holotype from Molino Basin, Santa Catalina Mtns., Pima Co., Arizona, in the Museum of Comparative Zoology.

Discussion. The female of $O$. felinus is described here for the first time. A male from Mexico is also described and illustrated for comparison to the holotype. 

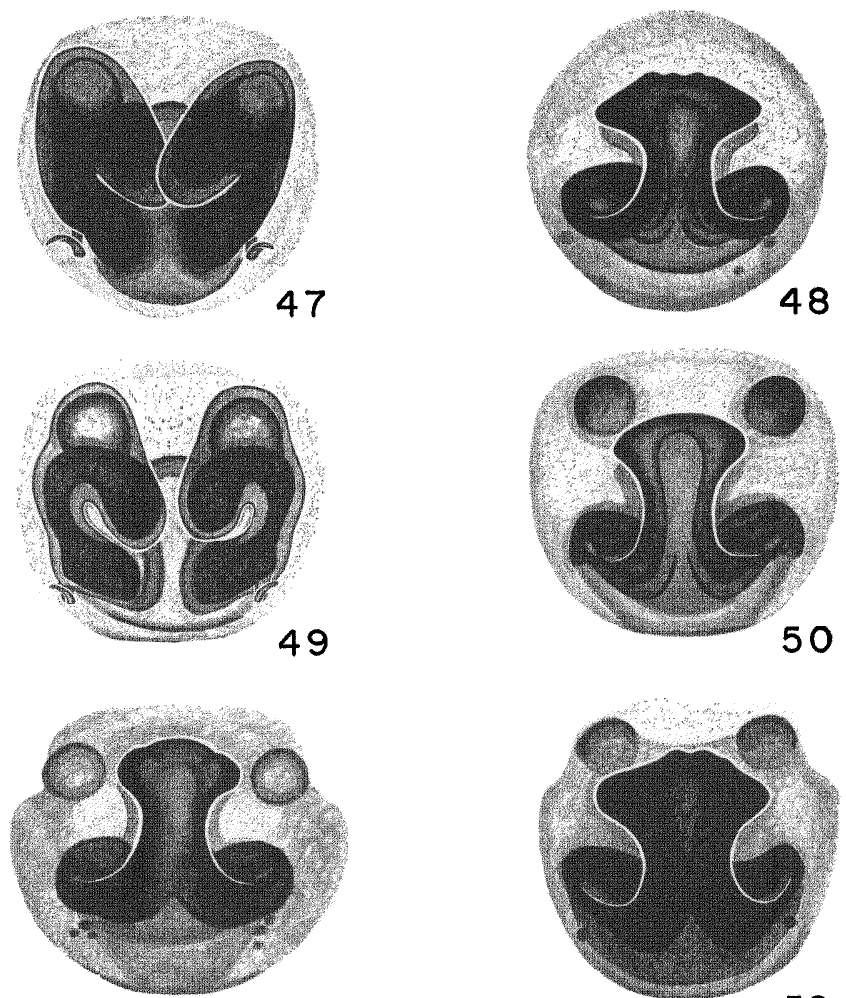

51
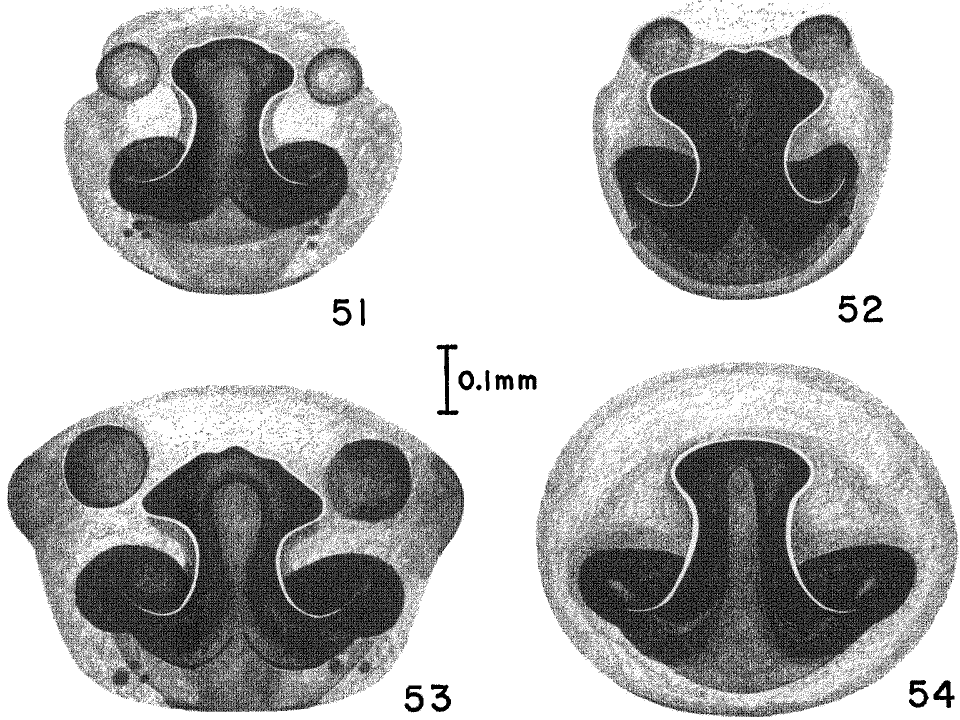
Measurements. Seven females and four males.

\begin{tabular}{|c|c|c|c|c|c|}
\hline FEMALES: & Mean & Range & & Mean & Range \\
\hline Clypeus & .460 & $.43-.50$ & Femur I & 1.66 & $1.6-1.8$ \\
\hline AME & .290 & $.28-.30$ & Patella-Tibia I & 1.94 & $1.9-2.0$ \\
\hline ALE & .525 & $.50-.55$ & Metatarsus I & 1.70 & $1.6-1.9$ \\
\hline PLE & .965 & $.93-1.00$ & Tarsus I & .73 & $.7-.8$ \\
\hline PME & .510 & $.48-.55$ & Total Length I & 6.04 & $5.8-6.4$ \\
\hline $\begin{array}{l}\text { Carapace } \\
\text { Width }\end{array}$ & 1.48 & $1.4-1.6$ & & & \\
\hline Carapace & 1.40 & $1.4-1.0$ & Patella-Tibia II & 1.79 & $1.6-1.9$ \\
\hline Length & 1.98 & $1.8-2.1$ & Patella-Tibia III & 1.35 & $1.2-1.5$ \\
\hline Total & & & Patella-Tibia IV & 1.97 & $1.8-2.1$ \\
\hline Length & 4.96 & $4.3-5.7$ & Total Length IV & 7.12 & $6.8-7.6$ \\
\hline MALES: & & Range & & & Range \\
\hline Clypeus & & $.43-.45$ & Femur I & & 1.7 \\
\hline AME & & $.28-.30$ & Patella-Tibia I & & $2.0-2.2$ \\
\hline ALE & & $.50-.53$ & Metatarsus I & & $2.0-2.1$ \\
\hline PLE & & $.93-.98$ & Tarsus I & & $.8-.9$ \\
\hline PME & & $.48-.53$ & Total Length I & & $6.5-6.8$ \\
\hline $\begin{array}{l}\text { Carapace } \\
\text { Width }\end{array}$ & & $1.4-1.5$ & & & \\
\hline Carapace & & & Patella-Tibia II & & $1.8-2.0$ \\
\hline Length & & $1.9-2.0$ & Patella-Tibia III & & $1.4-1.5$ \\
\hline Total & & & Patella-Tibia IV & & $2.0-2.1$ \\
\hline Length & & $4.2-4.4$ & Total Length IV & & $7.2-7.6$ \\
\hline
\end{tabular}

Color. Female. Face and chelicerae white to cream with wide dark brown stripes from ALE to distal end of chelicerae as in Figure 2I. Eye region dark brown to black overlaid with white spatulate-shaped hair.

Figs. 47-48. Oxyopes flavus Banks, female from Iquala, Guerrero, 27 Oct. 1947. 47. Internal genitalia. 48. Epigynum.

Figs. 49-50. Oxyopes flavus Banks, female from Tonala, Chiapas, Aug. 1909. 49. Internal genitalia. 50. Epigynum.

Fig. 51. Oxyopes flavus Banks, epigynum of female from Alamos, Sonora, 7 Aug. 1956.

Fig. 52. Oxyopes lingulifer F.O.P.-Cambridge $=0$. flavus, epigynum of female holotype from Costa Rica.

Fig. 53. Oxyopes flavus Banks, epigynum of female from Valles, San Luis Potosi, 19 July 1956.

Fig. 54. Oxyopes flavus Banks, epigynum of female syntype from Sierra San Lazaro, Baja California. 


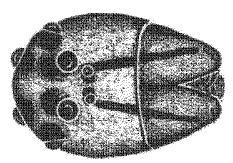

0
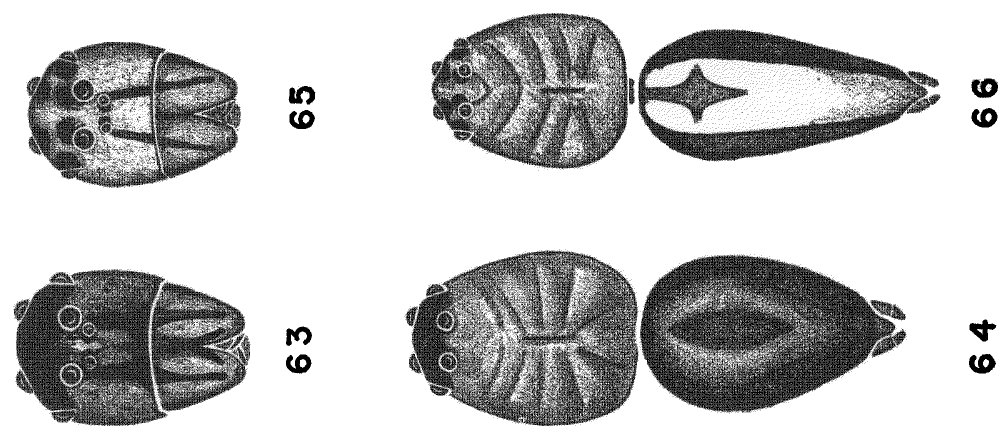

$m$
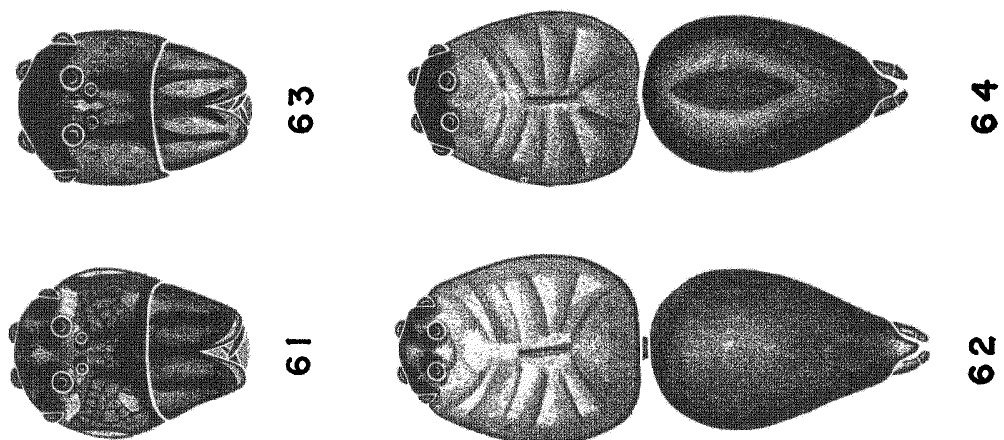

$\overline{6}$
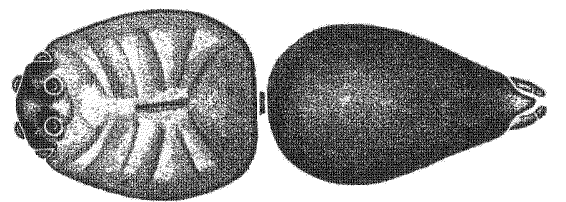

$\boldsymbol{N}$
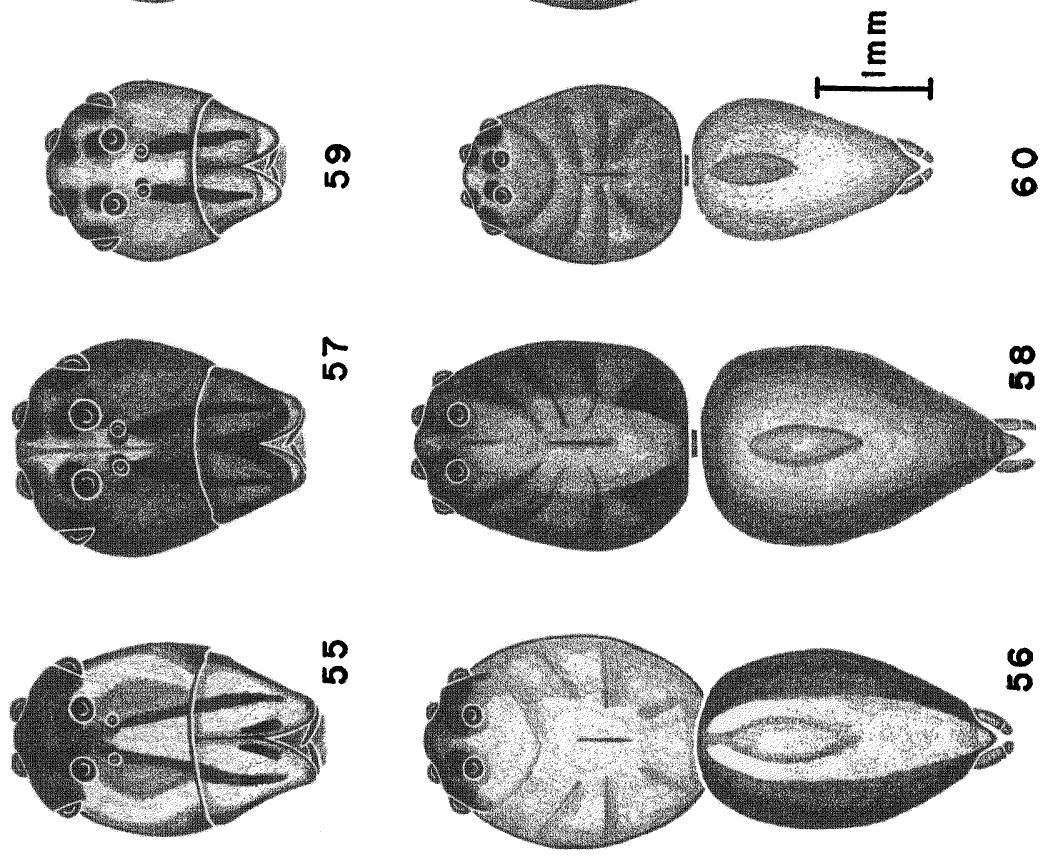
Carapace cream to golden yellow with broad dark brown submarginal stripes as in Figure 22.

Dorsum of abdomen with cardiac area translucent cream, outlined with brown. Median area white to cream with lateral areas darker, mottled with dark brown or black against white as in Figure 22. Venter with dark brown median stripe, divided longitudinally into three narrower stripes, bounded on its edges by white or cream. Sides mottled brown and cream.

Legs yellow. Distal ends of femora and tibia with irregular dark markings. A pair of dark ventro-lateral stripes on femora I-III.

Labium brown with lighter yellow anterior end. Endites yellow. Sternum yellow with brown splotches near base of femora.

Color. Male. Face and chelicerae orange-brown with the central area of the face black and lateral areas thickly clothed with white hair as in Figure 69 or face orange-brown with two broad vertical black stripes from ALE to subdistal region of chelicerae. Eye region black.

Carapace yellow-orange with wide dark brown submarginal stripes as in Figure 70.

Dorsum of abdomen with white median longitudinal stripe from base to tip of spinnerets, bordered by dark brown to black as in Figure 70. Venter with broad median black stripe beginning over genital area and continuing to base of spinnerets. Black stripe outlined in cream or pale yellow, darker mottled brown along sides. Metallic sheen from transparent appressed hairs.

Legs yellow with dusky ventral surface.

Labium dark brown. Endites dark brown with distal ends yellow. Sternum yellow with dusky patches near base of coxae.

Figs. 55-56. Oxyopes bifidus F.O.P.-Cambridge, male from Compostela, Nayarit, 12 July 1972. 55. Face view. 56. Dorsal view.

Figs. 57-58. Oxyopes bifissus F.O.P.-Cambridge, male from Tamazunchale, San Luis Potosi, 19 April 1963. 57. Face view. 58. Dorsal view.

Figs. 59-60. Oxyopes bifissus F.O.P.-Cambridge, male from Palomares, Oaxaca, July 1909. 59. Face view. 60. Dorsal view.

Figs. 61-62. Oxyopes tibialis F.O.P.-Cambridge, male from E of Tela, Honduras, 26 July 1924. 61. Face view. 62. Dorsal view.

Figs. 63-64. Oxyopes chiapas new species, male holotype from La Zacualpa, Chiapas, Aug. 1909. 63. Face view. 64. Dorsal view.

Figs. 65-66. Oxyopes summus new species, male holotype from Summit, Panama Canal Zone, 21-29 July 1950. 65. Face view. 66. Dorsal view. 
Diagnosis. Oxyopes felinus has the over-all black and white color pattern of other members of the tridens group. It does not have a strongly developed patellar apophysis, such as that found in $O$. tridens and $O$. pardus, but has a small protuberance on the patella. Oxyopes felinus is most closely related to $O$. cornutus, resembling this species in color and male and female reproductive organs. It can be distinguished from $O$. cornutus by reference to the epigyna (compare Figs. 39, 40 with Figs. 43, 44) and the male palpi (compare Figs. I02, 103 with Figs. I04, I05).

Distribution. Arizona, Sinaloa, Nayarit (Map 2).

Records. NORTH AMERICA. Arizona. Pima Co.: Molino Basin, Santa Catalina Mtns., I2 July 1962, ơ (ARB).

MEXICO. Nayarit. SW of Acaponeta, I5 May 1963, $30^{\pi} 0^{\pi}$ : 7 우우 :900 (WJG, WI). Sinaloa. Rosario, I5 May 1963, $0^{\star}$ (WJG, WI).

\section{Oxyopes cornutus F.O.P.-Cambridge}

Figures 19, 20, 43, 44, 67, 68, 82, 83, 104, 105. Map 2.

Oxyopes cornutus F.O.P.-Cambridge, 1902, Biologia Centrali-Americana, Arachnida, Araneidea, 2:343, pl. 32, fig. 16, $\hat{o}$. Male holotype from

Tierra Colorado, Guerrero, Mexico, in British Museum (Natural History), examined.

Discussion. The female of $O$. cornutus is described here for the first time and the male redescribed.

Measurements. Ten females and eight males.

\begin{tabular}{lcc|lcc} 
FEMALES: & Mean & Range & & Mean & Range \\
\hline Clypeus & .505 & $.43-.58$ & Femur I & 2.12 & $1.8-2.4$ \\
AME & .308 & $.30-.33$ & Patella-Tibia I & 2.50 & $2.2-2.8$ \\
ALE & .603 & $.55-.68$ & Metatarsus I & 2.31 & $2.0-2.8$ \\
PLE & 1.083 & $.98-1.20$ & Tarsus I & .84 & $.8-.9$ \\
PME & .580 & $.53-.65$ & Total Length I & 7.76 & $7.0-8.9$ \\
Carapace & & & & & \\
Width & 1.66 & $1.5-1.9$ & Patella-Tibia II & 2.29 & $2.1-2.7$ \\
$\begin{array}{l}\text { Carapace } \\
\text { Length }\end{array}$ & 2.23 & $1.8-2.7$ & Patella-Tibia III & 1.65 & $1.4-1.9$ \\
Total & & & Patella-Tibia IV & 2.42 & $2.1-2.8$ \\
Length & 5.80 & $4.7-7.2$ & Total Length IV & 8.66 & $7.5-9.9$ \\
\hline
\end{tabular}




\begin{tabular}{|c|c|c|c|c|c|}
\hline MALES: & Mean & Range & & Mean & Range \\
\hline Clypeus & .438 & $.35-.50$ & Femur I & 2.14 & $1.9-2.3$ \\
\hline AME & .290 & $.25-.30$ & Patella-Tibia I & 2.62 & $2.4-2.9$ \\
\hline ALE & .560 & $.50-.63$ & Metatarsus I & 2.61 & $2.3-2.9$ \\
\hline PLE & 1.023 & $.93-1.15$ & Tarsus I & 1.02 & $.9-1.1$ \\
\hline PME & .550 & $.50-.60$ & Total Length I & 8.40 & $7.5-9.2$ \\
\hline $\begin{array}{l}\text { Carapace } \\
\text { Width }\end{array}$ & 1.59 & $1.5-1.7$ & & & \\
\hline Carapace & & & Patella-Tibia II & 2.36 & $2.2-2.6$ \\
\hline Length & 2.10 & $1.9-2.4$ & Patella-Tibia III & 1.64 & $1.5-1.8$ \\
\hline Total & & & Patella-Tibia IV & 2.34 & $2.2-2.5$ \\
\hline Length & 4.80 & $4.3-5.3$ & Total Length IV & 8.39 & $7.6-8.9$ \\
\hline
\end{tabular}

Color. Female. Face and chelicerae white with a pair of wide dark brown stripes from ALE to subdistal ends of chelicerae as illustrated in Figure 19.

Carapace with median area white, bounded by wide dark brown submarginal stripes, with white at margins as in Figure 20.

Dorsum of abdomen with median white stripe outlined in black, becoming dark brown laterally. Two pairs of white marks posteriorly as in Figure 20. Venter with median area dusky, bounded by pale cream, becoming darker (light brown) laterally.

Legs yellow to light brown, overlaid with dark hair. Femora with dark stripe along anterio-ventral surface.

Labium and endites yellow. Sternum cream to pale yellow.

Color. Male. Face with dark brown or black median area bounded by white and chelicerae with vertical black stripes as in Figure 67. Eye region black. Cymbia of palpi black.

Carapace with broad median white stripe bounded by wide submarginal stripes, with the margins of the carapace white as in Figure 68.

Dorsum of abdomen with a median stripe bounded by black as in Figure 68.

Venter with dark brown median stripe outlined in pale cream to yellow and becoming darker laterally.

Legs yellow to brown, overlaid with dusky hair, without distinct darker markings.

Labium and endites pale yellow. Sternum cream to pale yellow.

Diagnosis. Oxyopes cornutus, particularly the male, has a black and white color pattern similar to $O$. tridens and $O$. pardus. The male of $O$. cornutus lacks a patellar apophysis such as that found in 

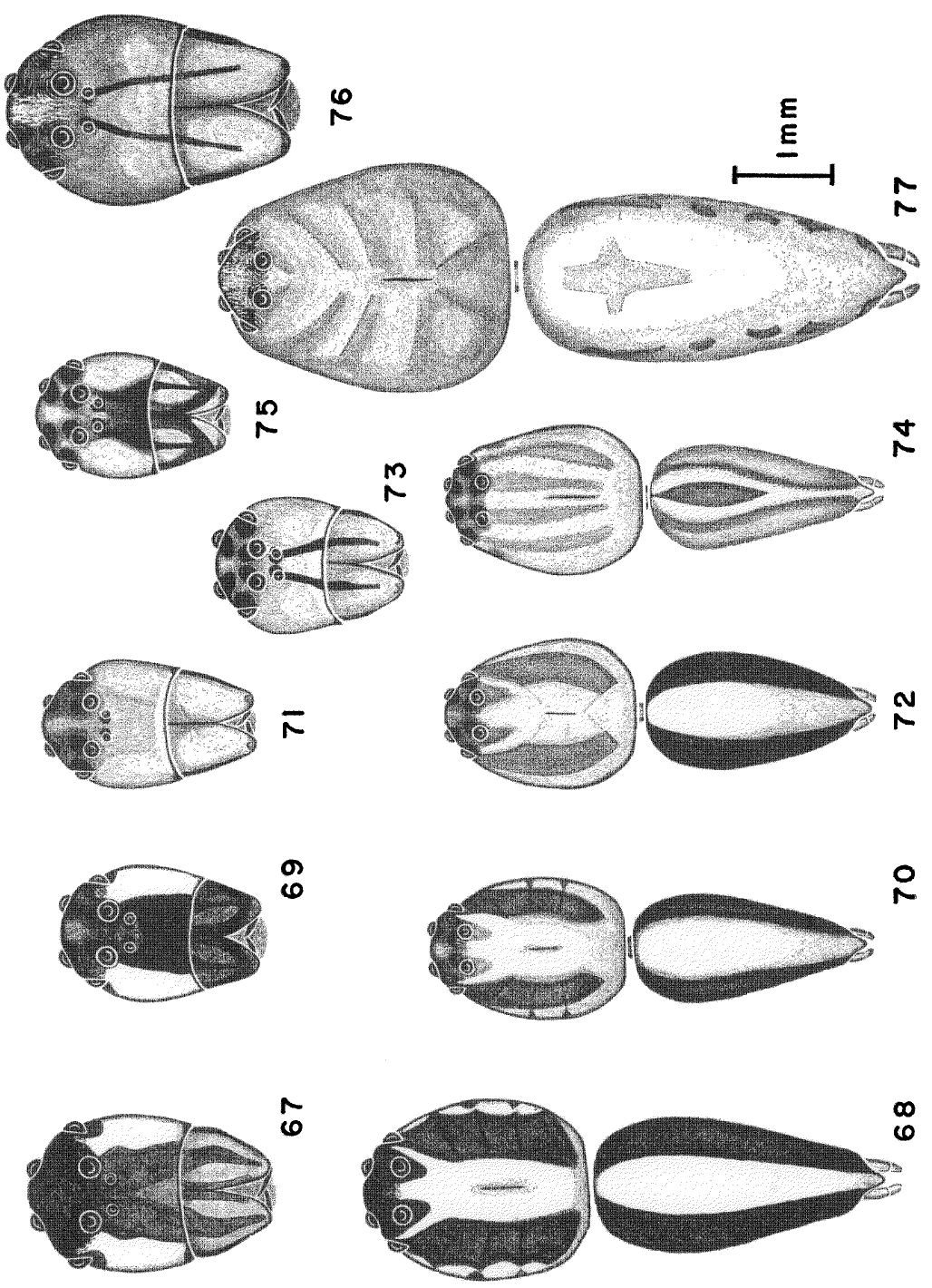
$O$. tridens and $O$. pardus. Oxyopes cornutus appears to be most closely related to $O$. felinus in male palpal structure and female epigynal structure. It can, however, be readily separated from $O$. felinus by comparing the male palpi (compare Figs. I04, IO5 with Figs. IO2, IO3) and female epigyna (compare Figs. 43, 44 with Figs. 39, 40).

Natural History. Oxyopes cornutus is not as well represented in collections as $O$. salticus or $O$. bifidus. It is apparently not often taken by sweeping vegetation. A number of these spiders were observed as they were running and jumping over a rock slide in Zopilote Canyon, Io mi $\mathbf{N}$ of Zumpango del Río. This was an old rock slide with sparse, grassy vegetation growing among the rock rubble. The over-all background color of this substrate was gray, and the black and white pattern of $O$. cornutus blended well with this particular habitat. The spiders became conspicuous only when they moved. Specimens from the rock slide were collected by hand since there was not enough vegetation to employ a sweep net.

The occurrence of Oxyopes cornutus in a rather dry, rocky habitat with little vegetation fits well with what is known of the biology of the tridens species group so far as I've observed. Members of this group appear to have an ecological niche quite distinct from members of the acleistus group which occur in considerable numbers in grassy and herbaceous vegetation.

Distribution. Colima, Guerrero, and Morelos (Map 2).

Records. Colima. $8 \mathrm{mi}$. SW of Colima, ro May I963, $0^{x} 0^{\star}$ : 4 우우 :oo (WJG, WI) ; $7 \mathrm{mi}$. SE of Manzanillo, I6 July I972, $\sigma^{\star}$ (AJ). Guerrero. Tierra Colorado, o (HHS), 22-23 July I972, $3 \sigma^{\top} \sigma^{\top}:$ 우 : IOoo (ARB) ; IO mi. N of Zumpango del Río, 23 July I972, 중 우우 :400 (ARB, AJ). Morelos. Acatlipa, ro Aug. 1946, 우우 ( $\mathrm{CG}, \mathrm{FB})$.

Figs. 67-68. Oxyopes cornutus F.O.P.-Cambridge, male from $8 \mathrm{mi}$. SW of Colima, Colima, 10 May 1963. 67. Face view. 68. Dorsal view.

Figs. 69-70. Oxyopes felinus Brady, male from SW of Acaponeta, 15 May 1963. 69. Face view.70. Dorsal view.

Figs. 71-72. Oxyopes ocelot new species, male holotype from $\mathrm{W}$ of Lake Sayula, Jalisco, 3 Aug. 1956. 71. Face view. 72. Dorsal view.

Figs. 73-75. Oxyopes salticus Hentz, males from Veracruz, Veracruz, 30 July 1972. 73. Face view. 74. Dorsal view. 75. Face view, indicating variation in color pattern.

Figs. 76-77. Oxyopes flavus Banks, male from Tierra Colorado, Guerrero, 23 July 1972. 76. Face view. 77. Dorsal view. 


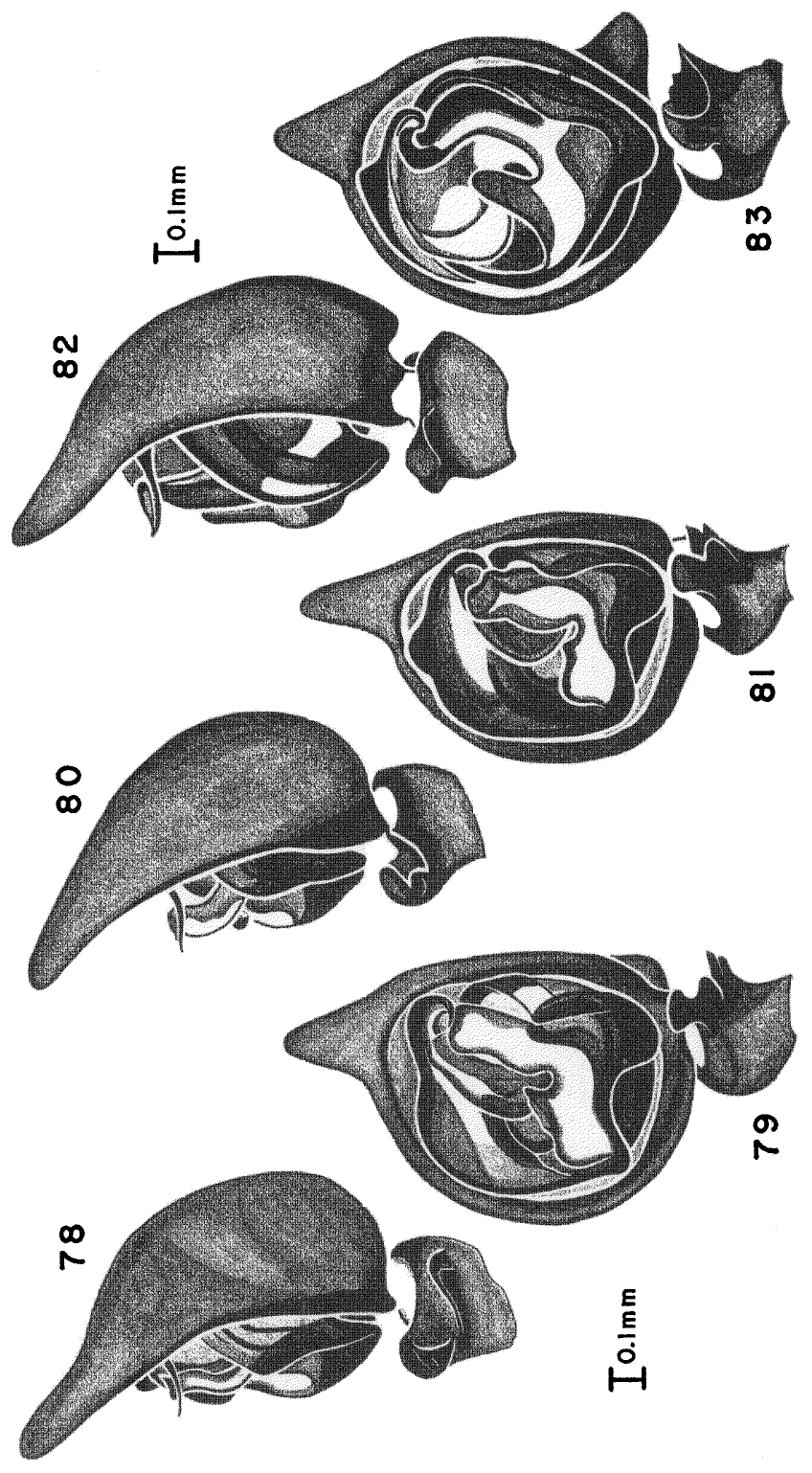




\section{Oxyopes panther new species}

Figures I 5, I6, 45, 46. Map 2.

Oxyopes sp. Brady, 1969, Psyche, 76(4):437, figs. 5, 6, 16, 17, $\&$. Female from $12 \mathrm{mi}$. W of Portal, Cochise Co., Arizona, 13 July 1968, in the Museum of Comparative Zoology.

Holotype. Female from $12 \mathrm{mi}$. W of Portal, Cochise Co., Arizona, I3 July 1968, (L. D. Mikelson) in the Museum of Comparative $Z$ oology. The specific name is a noun in apposition after the Panther.

Discussion. In an earlier paper on the apollo species group I illustrated and described an unknown female Oxyopes from Portal, Arizona (Brady, 1969). Since the females of $O$. pardus, O. lynx, and $O$. felinus were unknown at that time, I thought it best not to assign a distinctive name to a single female specimen that belonged to the same species group. During the present study four additional females of this same species were found in collections from Mexico. Although the male is still not known, I have decided to name the females in order that they can be identified. The actual relationship of these five females to $O$. pardus will be determined only when males and females are found in association.

Measurements. For measurements of the holotype see Brady, 1969. The range for the four Mexican females is given below.

Measurements. Four females.

\begin{tabular}{lc|lc} 
FEMALES: & Range & & Range \\
\hline Clypeus & $.55-.58$ & Femur I & $1.9-2.2$ \\
AME & $.30-.33$ & Patella-Tibia I & $2.1-2.5$ \\
ALE & $.53-.58$ & Metatarsus I & $2.0-2.2$ \\
PLE & $1.00-1.08$ & Tarsus I & $.8-1.0$ \\
PME & $.53-.58$ & Total Length I & $6.8-7.8$ \\
Carapace & & & \\
Width & $1.7-1.9$ & Patella-Tibia II & $2.1-2.4$ \\
Carapace & & Patella-Tibia III & $1.6-1.9$ \\
Length & $2.2-2.5$ & Patella-Tibia IV & $2.4-2.8$ \\
Total & & Total Length IV & $8.4-9.8$ \\
Length & $5.9-7.2$ &
\end{tabular}

Figs. 78-79. Oxyopes bifidus F.O.P.-Cambridge, male from Compostela, Nayarit, 12 July 1972. 78. Left palpus, retrolateral view. 79. Left palpus, ventral view.

Figs. 80-81. Oxyopes bifidus F.O.P.-Cambridge, male holotype from Acapulco, Guerrero. 80. Retrolateral view. 81. Ventral view.

Figs. 82-83. Oxyopes cornutus F.O.P.-Cambridge, male holotype from Tierra Colorado, Guerrero. 82. Retrolateral view. 83. Ventral view.

Scale on the left is for Figs. 78-79. Scale on the right is for Figs, 80-83. 
Color. Female from Mexico. Face and chelicerae pale cream to yellow, overlaid with white appressed hair. Brown stripes from AME to subdistal region of chelicerae as in Figure 15. Eye nacelles black, covered with white hair.

Carapace yellow, overlaid with white spatulate-shaped hair. Wide dark brown submarginal stripes as in Figure 16.

Dorsum of abdomen with broad median white stripe outlined with brown; brown mottled with white along sides as in Figure 16. Venter with a wide mottled brown and yellow median stripe from epigastric furrow to base of spinnerets. This stripe surrounded by pale cream laterally.

Legs yellow, shaded with brown.

Labium pale yellow, with brown along sides. Endites and sternum pale yellow.

Diagnosis. On the basis of morphological characteristics, color pattern, and the structure of the female genitalia $O$. panther belongs close to $O$. tridens. Since the female of $O$. pardus, another closely related species, is unknown, it is difficult to establish its relationship to $O$. panther. As has been suggested previously (Brady, 1969), $O$. panther may be the female of $O$. pardus. Until we have males and females collected together, it will be impossible to reach a decision. Oxyopes panther is easily distinguished from $O$. tridens by its epigynum (compare Figs. 43, 44 and figs. I6, I7 of Brady, I969 with figs. 53-55 of Brady, 1964).

Natural History. One note of interest is that $O$. panther has not been found below 6,000 feet in elevation. Altitudes are listed for specimens in the records below.

Distribution. Arizona, Chihuahua, and Durango (Map 2).

Records. NORTH AMERICA. Arizona. Cochise Co.: $12 \mathrm{mi}$. W of Portal, 6,000 ft. (I,830 m), I3 July I968, ㅇ (L. D. Mikelson).

MEXICO. Chihuahua. W summit of Primavera near Gallego, 7,000 ft. (2,135 m), 2 July 1947, 우 (WJG); NE summit of San José Babicora, $7,700 \mathrm{ft}$. $(2,350 \mathrm{~m}), 3$ July 1947 , + (WJG). Durango. Palos Colorados about $25 \mathrm{mi}$. W of Durango, 8,000 ft. (2,440 m), 5 Aug. 1947, ㅇ (WJG). 
Oxyopes ocelot new species

Figures I 7, 18, 4I, 42, 71, 72, IOO, IOI. Map 2.

Holotype. Male from W side of Lake Sayula, Jalisco, Mexico, 3 Aug. 1956, (W. J. Gertsch, V. D. Roth), in the American Museum of Natural History. The specific name is a noun in apposition after the Ocelot.

Measurements. Seven females and ten males.

\begin{tabular}{|c|c|c|c|c|c|}
\hline FEMALES: & Mean & Range & & Mean & Range \\
\hline Clypeus & .530 & $.45-.65$ & Femur I & 1.90 & $1.6-2.2$ \\
\hline AME & .320 & $.30-.33$ & Patella-Tibia I & 2.26 & $2.0-2.6$ \\
\hline ALE & .540 & $.50-.58$ & Metatarsus I & 2.00 & $1.7-2.3$ \\
\hline PLE & .990 & $.93-1.05$ & Tarsus I & .79 & $.7-.8$ \\
\hline PME & .540 & $.50-.58$ & Total Length I & 6.96 & $6.0-7.8$ \\
\hline $\begin{array}{l}\text { Carapace } \\
\text { Width }\end{array}$ & 1.66 & $1.5-1.9$ & & & \\
\hline Carapace & & & Patella-Tibia II & 2.10 & $1.8-2.4$ \\
\hline Length & 2.26 & $2.0-2.6$ & Patella-Tibia III & 1.62 & $1.4-1.8$ \\
\hline Total & & & Patella-Tibia IV & 2.49 & $2.2-2.8$ \\
\hline Length & 5.90 & $4.9-6.9$ & Total Length IV & 8.76 & $7.9-9.7$ \\
\hline MALES: & Mean & Range & & Mean & Range \\
\hline Clypeus & .445 & $.43-.48$ & Femur I & 1.77 & $1.6-2.0$ \\
\hline AME & .285 & $.25-.33$ & Patella-Tibia I & 2.21 & $2.0-2.5$ \\
\hline ALE & .480 & $.45-.53$ & Metatarsus I & 2.10 & $1.9-2.4$ \\
\hline PLE & .883 & $.80-.98$ & Tarsus I & .86 & $.8-1.0$ \\
\hline PME & .478 & $.45-.53$ & Total Length I & 6.94 & $6.3-7.8$ \\
\hline $\begin{array}{l}\text { Carapace } \\
\text { Width }\end{array}$ & 1.47 & $1.3-1.6$ & & & \\
\hline Carapace & & & Patella-Tibia II & 2.01 & $1.9-2.3$ \\
\hline Length & 1.97 & $1.8-2.2$ & Patella-Tibia III & 1.51 & $1.4-1.7$ \\
\hline Total & & & Patella-Tibia IV & 2.26 & $2.0-2.5$ \\
\hline Length & 4.20 & $3.6-4.6$ & Total Length IV & 7.97 & $7.3-8.8$ \\
\hline
\end{tabular}

Color. Female. Face and chelicerae yellow to yellow-orange with faint darker vertical stripes from AME to subdistal region of chelicerae as in Figure 17. Eye nacelles black. Lower edge of clypeus lighter, pale yellow.

Carapace pale yellow to yellow with a pair of wide brown submarginal stripes as in Figure 18. 


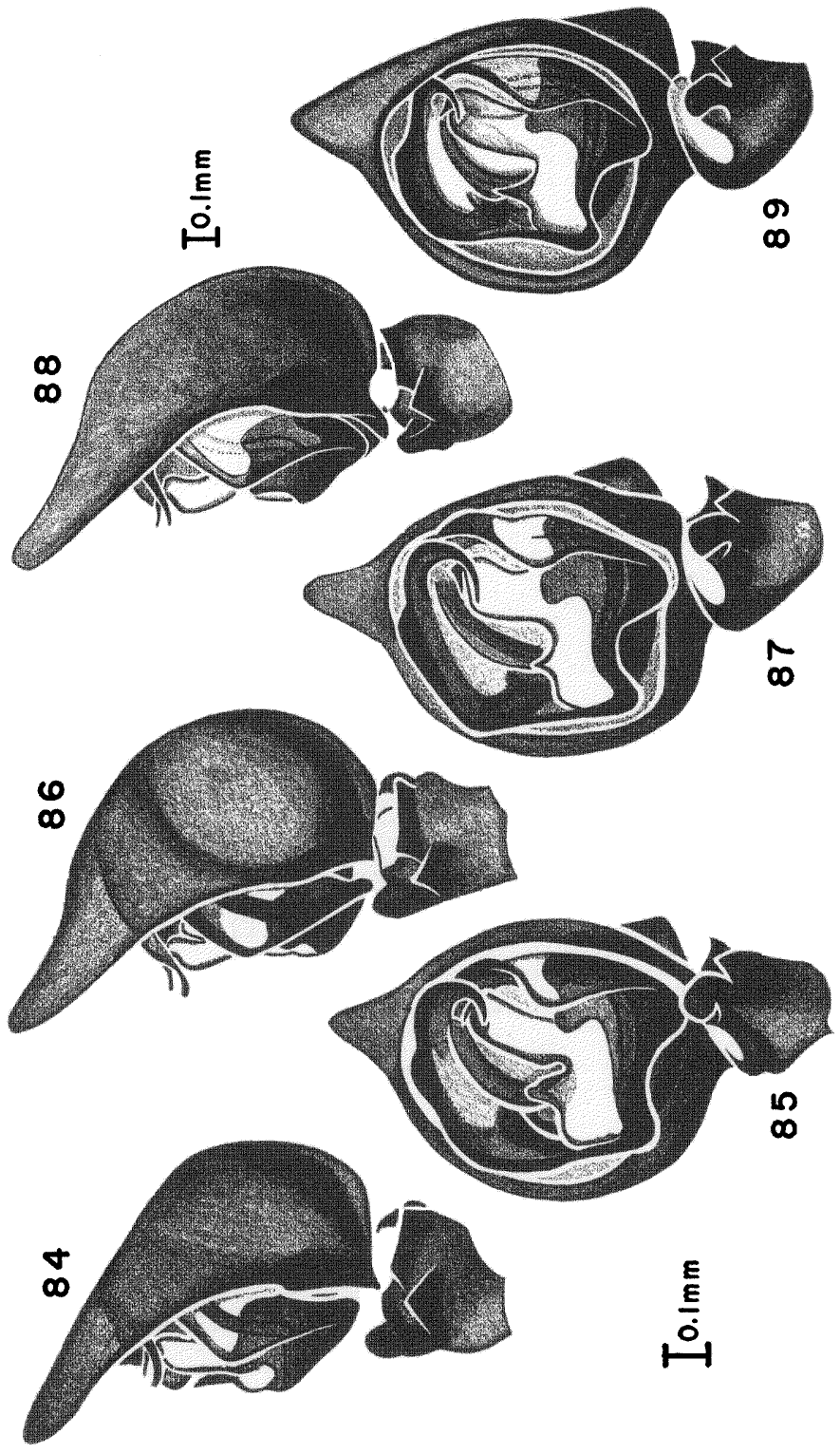


Dorsum of abdomen dark brown with a wide median white stripe as in Figure 18. Sides of abdomen pale yellow with irregular brown spots. Venter with a wide brown stripe from epigastric furrow to base of spinnerets, outlined by white or pale yellow.

Legs yellow to yellow-orange with mid-ventral black stripe on femora I and II.

Labium pale yellow, brownish along sides. Endites pale yellow. Sternum cream to pale yellow.

Color. Male. Face and chelicerae pale yellow to light orange without darker markings, with lower edge of clypeus cream as in Figure 7 I. Palpi light to dark brown.

Carapace yellow to pale yellow-orange with darker brown submarginal stripes as in Figure 72.

Dorsum of abdomen with broad white median stripe bordered by dark brown to black as in Figure 72. Venter with wide median brownish stripe from epigastric furrow to base of spinnerets, bordered by lighter cream.

Legs pale yellow with mid-ventral black lines on femora I-II.

Labium and endites pale yellow. Sternum cream to pale yellow.

Dark Male. A single darker colored male has the face and chelicerae orange brown without distinct darker markings. Cymbia of palpi black.

Carapace yellow-orange with dark brown submarginal stripes.

Dorsum with broad white median stripe overlaid with darker scale-like hairs. Venter with median stripe dark brown to black.

Diagnosis. Oxyopes ocelot has the well-developed fourth pair of legs and the broad median white stripe of the abdomen flanked by black that is characteristic of the tridens species group. The face is not strongly marked as in other members of the group, however. The palpal organ of the male and to a lesser extent the epigynum of this species place it closest to O. cornutus. Oxyopes ocelot is distinguished from this species by its coloration and the distinctive male palpus (compare Figs. IOO, IOI to Figs. I04, I05) and female epigynum (compare Figs. 4I, 42 with Figs. 43, 44).

Figs. 84-85. Oxyopes calcarifer F.O.P.-Cambridge $=0$. bifissus, male holotype from Costa Rica. 84. Retrolateral view. 85. Ventral view.

Figs. 86-87. Oxyopes bifissus F.O.P.-Cambridge, male lectotype from Teapa, Tabasco. 86. Retrolateral view. 87. Ventral view.

Figs. 88-89. Oxyopes bifissus F.O.P.-Cambridge, male from Compostela, Nayarit, 12 July 1972. 88. Left palpus, retrolateral view. 89. Left palpus, ventral view.

Scale on the left is for Figs. 84-87.

Scale on the right is for Figs. 88-89. 


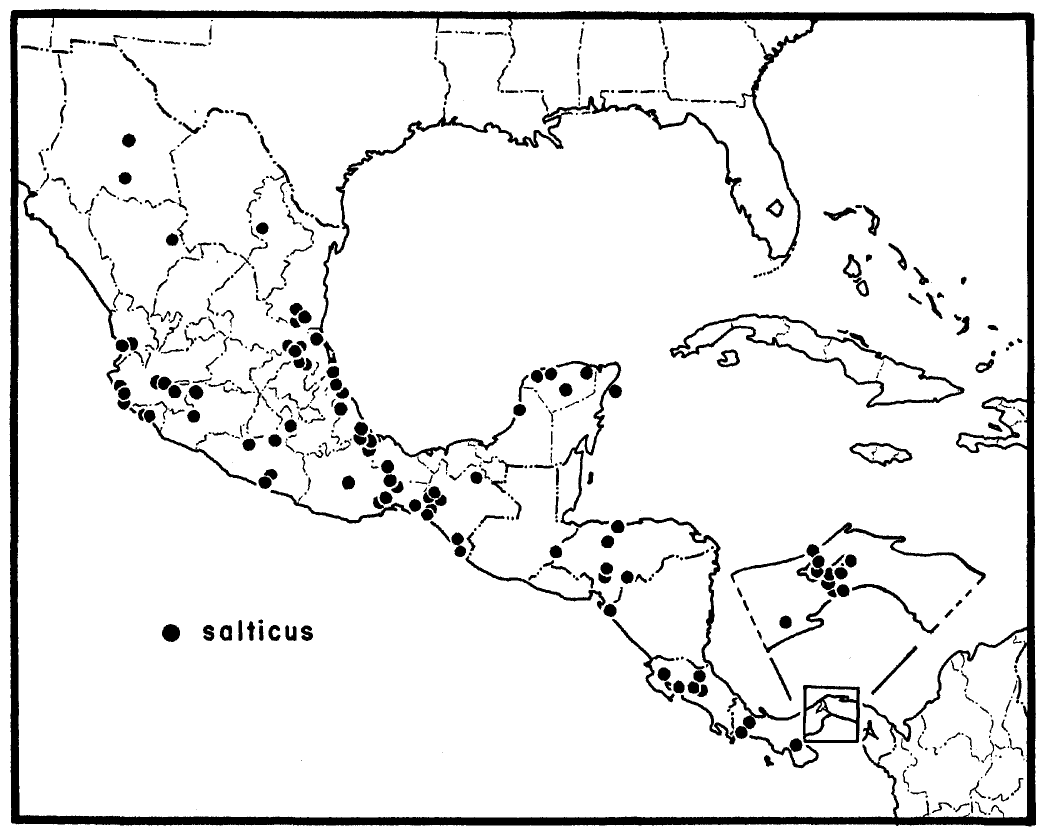

Map 3.

Distribution. Puebla, Morelos, Jalisco, Colima, and Guerrero. (Map 2).

Records. Puebla. Acatlan, 24-27 Sept. 1946, \& (HMW). Morelos. Alpoyeca, 28 July I956, $0^{*}$ (WJG, VDR). Jalisco. Guadalajara, I9 Sept. 1957, $\sigma^{*}$ (RD); La Venta, I9 July I953, $0^{*}$ (Albert Robinson, Jr.) ; W side of Lake Sayula, 3 Aug. 1956, $\sigma^{\pi} \sigma^{\pi}$ (WJG, VDR). Colima. $20 \mathrm{mi}$. N of Colima, 2 Aug. 1956, + (VDR, WJG). Guerrero. Arcelia, 2 Nov. 1947, $50^{x} 0^{x}: 4$ ㅇ $q$ :o (HMW).

\section{Oxyopes scalaris Hentz Map 4.}

Oxyopes scalaris Hentz, 1845, Boston Jour. Nat. Hist., $5: 196$, pl. 17, fig. 4, 9. Female syntypes from North Carolina, lost; ibid., 1875, Occ. Pap. Boston Soc. Nat. Hist., $2: 47$, pl. 7, fig. 4, pl. 19, fig. 120, + . Roewer, 1954, Katalog der Araneae, 2 (a) :334. Bonnet, 1958, Bibliographia Araneorum, 2(4) :3241. Brady, 1964, Bull. Mus. Comp. Zool., 131 (13) : 484, figs. 87-90, 97-99, 106, 107, 수우.

Discussion. For a list of synonyms, measurements, illustrations, color descriptions, natural history, and records north of Mexico see Brady, 1964, pages 484-495. 
Diagnosis. Oxyopes scalaris is unlike any other Mexican or Central American species of Oxyopes, although it clearly falls within the limits of the genus. The closest relatives of $O$. scalaris appear to be certain European species, such as $O$. ramosus or $O$. heterophthalamus (Brady, I964).

Oxyopes scalaris can be easily recognized by the epigynum (figs. 97-99 of Brady, I964) and the male palpus (figs. I06, I07 of Brady, I964).

Distribution. Canada to northern Mexico.

Records. MEXICO. Chihuahua. $25 \mathrm{mi} \mathrm{W}$ of Camargo, I3 July I947, $\sigma^{x}$, Huejotitlan, 20 July i947, + , Matachic, 6 July I947, + (WJG).

\section{Oxyopes salticus Hentz}

Figures I I, I2, 23, 24, 73-75, 98, 99. Map 3.

Oxyopes salticus Hentz, 1845, Boston Jour. Nat. Hist., 5 :196, pl. 16, fig. 10, . Female syntypes from North Carolina and Alabama, lost. Hentz, 1875, Occ. Pap. Boston Soc. Nat. Hist., 2:47, pl. 6, fig. 10, ㅇ. Roewer, 1954, Katalog der Araneae, 2(a):333. Bonnet, 1958, Bibliographia Araneorum, 2(4) :3240. Brady, 1964, Bull. Mus. Comp. Zool., 131(13) : 478, figs. 80-86, 91-96, 104, 105, ô 우.

Oxyopes luteus Blackwall, 1862, Ann. Mag. Nat. Hist. 10(3):350, ô $q$. Female holotype from Brazil in the University Museum, Oxford, England.

Oxyopes varians Taczanowski, 1873, Hor. Soc. Ent. Ross., 10:95, 오. Female holotype from French Guiana in Instytut Zool. Polska Akademia Nauk, Warsaw, Poland.

Oxyopes gracilis Keyserling, 1877, Verh. Zool.-Bot. Ges. Wien, 26:698, pl. 2, figs. 63, 64, 9 . Syntypes from New Granada (Panama, Ecuador, Peru, Colombia, Venezuela) in the British Museum (Natural History), examined. F.O.P.-Cambridge, 1902, Biologia Centrali-Americana, Arachnida, Araneidea $2: 343$, pl. 32, figs. 14, 14a, 14b, 15, 15a, 15b, î ㅇ․ Brady, 1964, Bull. Mus. Comp. Zool., 131(13):479, figs. 102, 103, ồ.

Discussion. In I963 I examined large numbers of $O$. salticus from North America southward to Brazil. I noted a slight difference in the structure of the male palpus in specimens from central Mexico southward (Brady, I964). Because of this difference (compare figs. IO2, IO3 to figs. I04, IO5 of Brady, I964) I decided to retain the name $O$. gracilis Keyserling for populations from central Mexico to Brazil. Having collected $O$. salticus in Mexico and Central America and examined numerous specimens from that area and South America, I have concluded that the slight differences in the male palpi between $O$. salticus and $O$. gracilis are simply a 


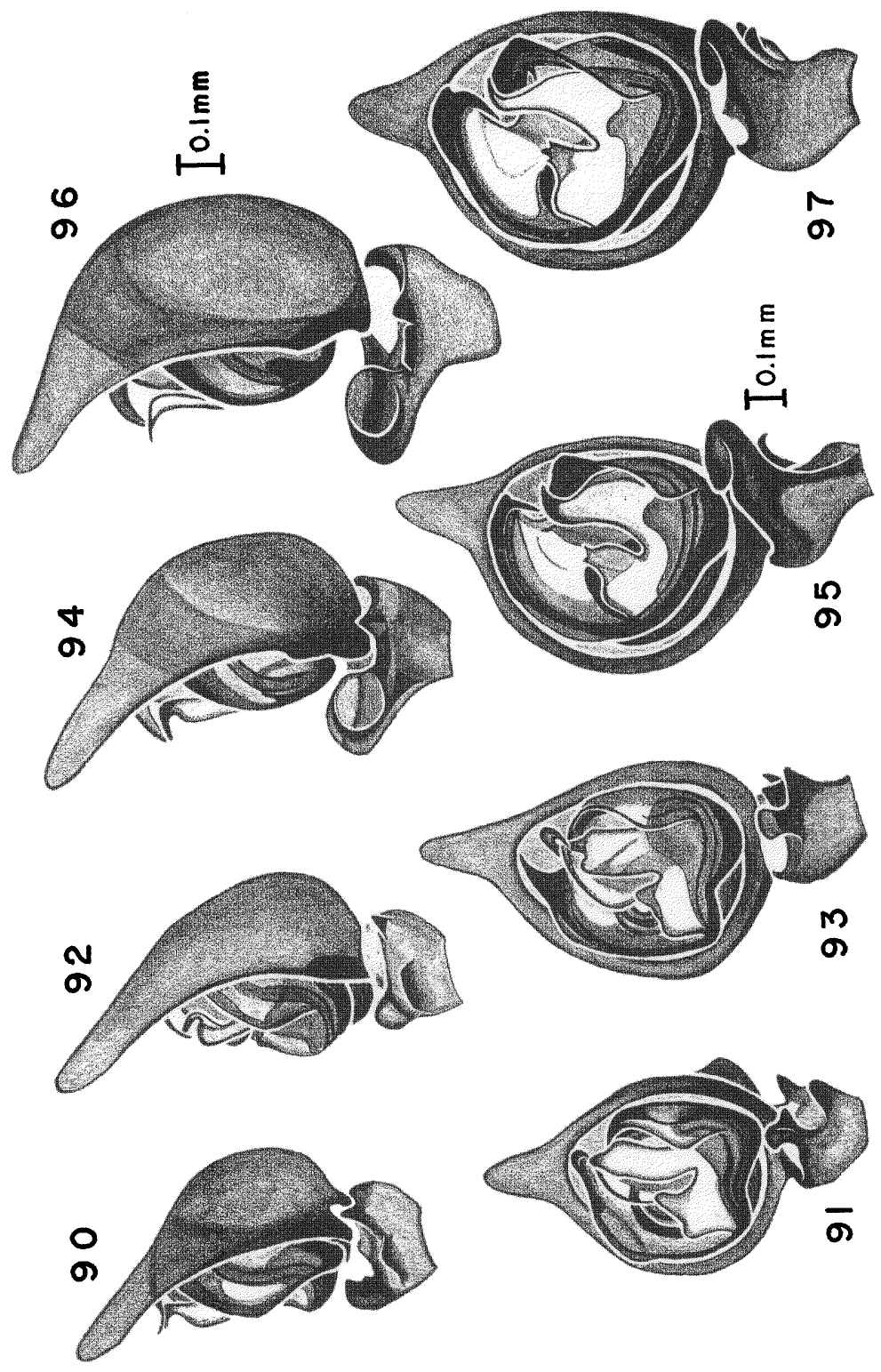


reflection of geographic variation. Therefore, I now consider $O$. gracilis, $O$. luteus, and $O$. varians to be junior synonyms of $O$. salticus. This decision has been influenced by the considerable amount of variation seen within local populations of Oxyopes in Mexico and Central America.

Measurements. Ten females and ten males.

\begin{tabular}{|c|c|c|c|c|c|}
\hline FEMALES: & Mean & Range & & Mean & Range \\
\hline Clypeus & .438 & $.38-.53$ & Femur I & 2.20 & $1.9-2.6$ \\
\hline AME & .310 & $.30-.35$ & Patella-Tibia I & 2.79 & 2.3-3.4 \\
\hline ALE & .510 & $.48-.58$ & Metatarsus I & 2.21 & $1.8-2.8$ \\
\hline PLE & .940 & $.85-1.05$ & Tarsus I & .95 & $.8-1.1$ \\
\hline PME & .508 & $.48-.58$ & Total Length I & 8.16 & $6.9-9.9$ \\
\hline $\begin{array}{l}\text { Carapace } \\
\text { Width }\end{array}$ & 1.64 & $14-19$ & & & \\
\hline Carapace & & & Patella-Tibia II & 2.58 & $2.1-3.2$ \\
\hline Length & 2.27 & $2.0-2.6$ & Patella-Tibia III & 2.00 & $1.6-2.4$ \\
\hline Total & & & Patella-Tibia IV & 2.38 & $2.0-2.8$ \\
\hline Length & 5.34 & $4.4-6.0$ & Total Length IV & 7.76 & $6.6-9.2$ \\
\hline MALES: & Mean & Range & & Mean & Range \\
\hline Clypeus & .395 & $.33-.45$ & Femur I & 2.13 & $1.8-2.4$ \\
\hline AME & .293 & $.28-.30$ & Patella-Tibia I & 2.73 & $2.3-3.0$ \\
\hline ALE & .473 & $.43-.50$ & Metatarsus I & 2.54 & $2.0-2.8$ \\
\hline PLE & .870 & $.75-.93$ & Tarsus I & 1.18 & $1.0-1.3$ \\
\hline PME & .473 & $.43-.50$ & Total Length I & 8.58 & $7.1-9.3$ \\
\hline $\begin{array}{l}\text { Carapace } \\
\text { Width }\end{array}$ & 1.64 & $1.4-1.8$ & & & \\
\hline $\begin{array}{l}\text { Carapace } \\
\text { Length }\end{array}$ & 2.18 & $1.8-2.4$ & $\begin{array}{l}\text { Patella-Tibia II } \\
\text { Patella-Tibia III }\end{array}$ & $\begin{array}{l}2.50 \\
1.95\end{array}$ & $\begin{array}{l}2.0-2.7 \\
1.6-2.1\end{array}$ \\
\hline $\begin{array}{l}\text { Total } \\
\text { Length }\end{array}$ & 4.46 & $3.7-4.8$ & $\begin{array}{l}\text { Patella-Tibia IV } \\
\text { Total Length IV }\end{array}$ & $\begin{array}{l}2.26 \\
7.73\end{array}$ & $\begin{array}{l}1.9-2.4 \\
6.5-8.4\end{array}$ \\
\hline
\end{tabular}

Figs. 90-91. Oxyopes summus new species, male holotype from Summit, Panama Canal Zone, 21-29 July 1950. 90. Left palpus, retrolateral view. 91. Left palpus, ventral view.

Figs. 92-93. Oxyopes chiapas new species, male holotype from La Zacualpa, Chiapas, Aug. 1909. 92. Retrolateral view. 93. Ventral view.

Figs. 94-95. Oxyopes tibialis F.O.P.-Cambridge, male from E of Tela, Honduras, 26 July 1929. 94. Retrolateral view. 95. Ventral view.

Figs. 96-97. Oxyopes tibialis F.O.P.-Cambridge, male lectotype from Guatemala. 96. Retrolateral view. 97. Ventral view.

Scale on left, below is for Figs. 90-95.

Scale on right, above is for Figs. 96-97. 
Color. Female. Face and chelicerae cream to pale yellow. Black stripes beginning under $\mathrm{AME}$ and continuing down chelicerae as in Figure II. A black dash and a spot below this in cheek area. Eye nacelles black, overlaid with white hair.

Carapace cream to pale yellow with four gray stripes as indicated in Figure 12. Gray stripes formed of appressed hairs, which are rubbed away in some specimens.

Dorsum with median area white with darker brown outlining cardiac area. White, pale yellow-orange, and brown spatulate hairs forming pattern illustrated in Figure 12. Venter with wide, dark brown median stripe beginning at epigastric furrow and continuing to base of spinnerets. Brown stripe is sometimes mottled.

Legs cream to pale yellow with black stripe on ventral surfaces of femora I-III.

Labium and endites cream to pale yellow. Sternum ivory to pale yellow, with four pairs of black spots at periphery.

Color. The male of $O$. salticus occurs in at least two different forms or morphs with some specimens intermediate. Two commonly occurring patterns are described below.

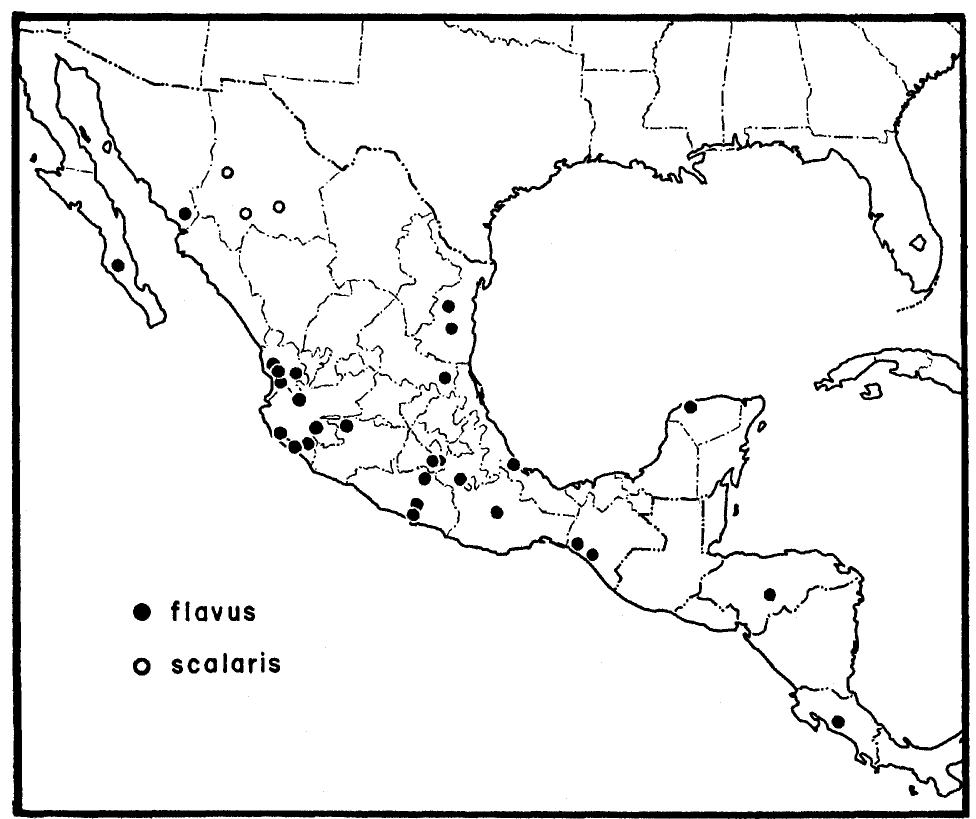

Map 4. 
Light Male. Face and chelicerae cream to pale yellow with vertical black stripes as indicated in Figure 73. Cymbia of palpi dark brown to black. Eyes with black nacelles overlaid with iridescent scale-like hairs.

Carapace pale yellow to light yellow-orange. A few faint dusky markings contributed by spatulate-shaped hairs as in Figure 74 .

Dorsum of abdomen cream to pale yellow, dusky laterally and along sides of abdomen. Scale like hairs providing a metallic green or pink sheen. Cardiac area outlined as in Figure 74. Venter with broad median brown stripe from epigastric furrow to base of spinnerets. The stripe outlined in white, with dusky color laterally.

Legs cream to pale yellow without stripes or dusky markings in most specimens. Mid-ventral black stripe on femora I and II of some.

Labium cream to pale yellow. Endites cream to pale yellow, outer margins darker brownish. Sternum yellow.

Dark Male. Face black between AME to clypeus and chelicerae with black markings as shown in Figure 75. Cymbia of palpi black.

Carapace pale yellow to light yellow-orange, with four longitudinal dusky stripes.

Dorsum of abdomen iridescent, mostly dark gray-brown to black. Venter dark gray-brown to black with white lines outlining median stripe conspicuously seen in lighter forms.

Legs cream to pale yellow. Patellae-tibiae and femora of palpi with black markings dominating lighter color.

Labium and endites black with distal ends pale cream. Sternum yellow with black periphery.

Diagnosis. Oxyopes salticus resembles members of the acleistus group with mid-ventral black stripes on the femora and vertical black lines on the face. It can be immediately distinguished by the peculiar shape of the epigynum (Figs. 23, 24) and the characteristic palpus of the male (Figs. 98, 99). The male palpus has a stout conical projection on the cymbium and a stout brush of short, stiffened bristles (not figured) on the ventral surface of the palpal tibia. Oxyopes salticus should be placed in a separate species group to reflect its relationship to other Mexican and Central American species.

Natural History. Oxyopes salticus is one of the most common spider inhabitants of tall grass and herbaceous vegetation and is found throughout Mexico and Central America wherever this type of vegetation occurs. The local abundance of these spiders gives evidence of their role as one of the important predators of insects 
238

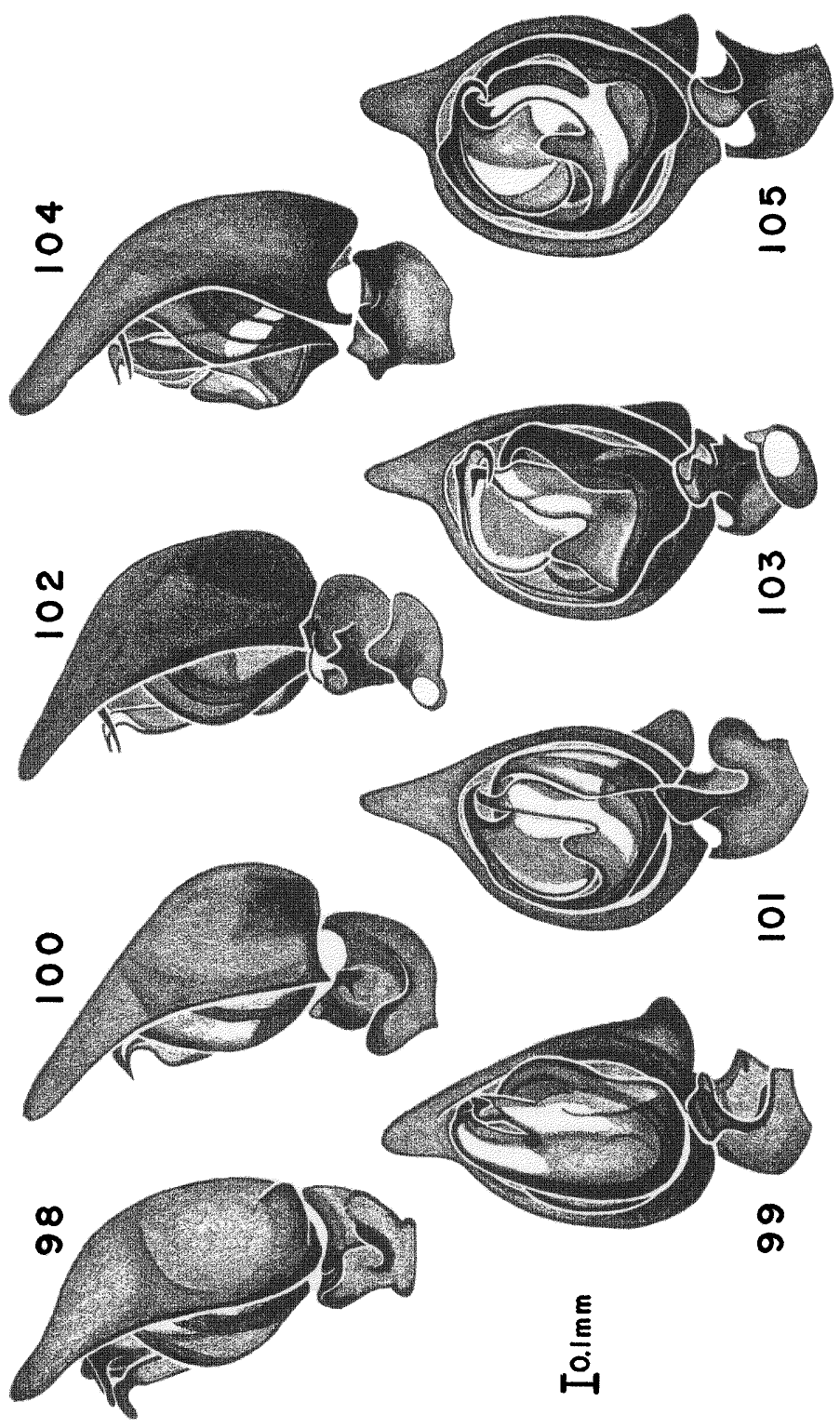


occurring in these habitats. For further notes on the biology of $O$. salticus see Brady (1964), pp. 481-482.

Distribution. North America (see Map 3 of Brady, I964), Mexico, Central America, Lesser Antilles, and South America.

Records. Common throughout Mexico and Central America (Map 3).

\section{Oxyopes flavus Banks}

Figures I3, I 4, 47-54, 76, 77, I06, I07. Map 4.

Oxyopes flavus Banks, 1898, Proc. Calif. Acad. Sci., 1(3):278, pl. 7, fig. 28, + . Female syntypes from Sierra San Lazaro, Baja California, Mexico, (G. Eisen, F. H. Vaslit), in Museum of Comparative Zoology, examined.

Oxyopes lingulifer F.O.P.-Cambridge, 1902, Biologia Centrali-Americana, Arachnida, Araneidea, 2:345, pl. 32, fig. 28, 9 . Female holotype from Costa Rica, (Rogers), in British Museum (Natural History), examined. NEW SYNONYMY.

Discussion. The specimens from Sierra San Lazaro upon which Banks ( I 898) based the name $O$. Alavus are at one extremity of the range of this species and the female holotype of Oxyopes lingulifer is from Costa Rica at the other end of the known range. Most of the other specimens are from in between (see Map 4). The epigynum of Cambridge's holotype (Fig. 52) seems to be quite different from that of $O$. flavus. An investigator might consider them distinct species. However, the epigyna of the specimens from geographic areas between these specimens show considerable variation (Figs. 47-5 I) and even specimens from the same locality may be different in this respect. Therefore, the type specimens of $O$. flavus and O. lingulifer are considered to be geographic variants of the same species. This species illustrates very well the greater amount of geographic and individual variation encountered in Mexican and Central American species when compared to their North American relatives.

Figs. 98-99. Oxyopes salticus Hentz, male from Veracruz, Veracruz, 30 July 1972. 98. Left palpus, retrolateral view. 99. Left palpus, ventral view.

Figs. 100-101. Oxyopes ocelot new species, male holotype from W side of Lake Sayula, Guerrero, 3 Aug. 1956. 100. Retrolateral view. 101. Ventral view.

Figs. 102-103. Oxyopes felinus Brady, male from SW of Acaponeta, Nayarit, 15 May 1963. 102. Retrolateral view. 103. Ventral view.

Figs. 104-105. Oxyopes cornutus F.O.P.-Cambridge, male from $8 \mathrm{mi}$. SW of Colima, Colima, 10 May 1963. 104. Retrolateral view. 105. Ventral view. 
Measurements. Ten females and ten males.

\begin{tabular}{|c|c|c|c|c|c|}
\hline FEMALES: & Mean & Range & & Mean & Range \\
\hline Clypeus & .708 & $.63-.80$ & Femur I & 3.39 & $2.9-3.9$ \\
\hline AME & .398 & $.35-.45$ & Patella-Tibia I & 4.28 & $3.7-4.9$ \\
\hline ALE & .648 & $.58-.70$ & Metatarsus I & 3.54 & $3.0-4.0$ \\
\hline PLE & 1.153 & $1.05-1.25$ & Tarsus I & 1.36 & $1.2-1.5$ \\
\hline PME & .648 & $.58-.70$ & Total Length I & 12.58 & $10.9-14.4$ \\
\hline $\begin{array}{l}\text { Carapace } \\
\text { Width }\end{array}$ & 2.38 & $2.1-2.7$ & & & \\
\hline $\begin{array}{l}\text { Carapace } \\
\text { Length }\end{array}$ & 3.10 & $2.7-3.6$ & $\begin{array}{l}\text { Patella-Tibia II } \\
\text { Patella-Tibia III }\end{array}$ & $\begin{array}{l}4.05 \\
3.11\end{array}$ & $\begin{array}{l}3.5-4.7 \\
2.6-3.6\end{array}$ \\
\hline $\begin{array}{l}\text { Total } \\
\text { Length }\end{array}$ & 8.47 & $7.2-9.2$ & $\begin{array}{l}\text { Patella-Tibia IV } \\
\text { Total Length IV }\end{array}$ & $\begin{array}{r}3.56 \\
11.59\end{array}$ & $\begin{array}{l}3.1-4.1 \\
9.9-13.4\end{array}$ \\
\hline MALES: & Mean & Range & & Mean & Range \\
\hline Clypeus & .548 & $.48-.65$ & Femur I & 3.02 & $2.4-3.5$ \\
\hline AME & .318 & $.30-.35$ & Patella-Tibia I & 4.02 & $3.1-4.5$ \\
\hline ALE & .558 & $.50-.63$ & Metatarsus I & 3.70 & $2.6-4.3$ \\
\hline PLE & 1.000 & $.95-1.05$ & Tarsus I & 1.69 & $1.3-2.1$ \\
\hline PME & .553 & $.50-.60$ & Total Length I & 12.44 & $9.4-14.4$ \\
\hline $\begin{array}{l}\text { Carapace } \\
\text { Width }\end{array}$ & 2.07 & $1.8-2.3$ & & & \\
\hline $\begin{array}{l}\text { Carapace } \\
\text { Length }\end{array}$ & 2.62 & $2.3-2.8$ & $\begin{array}{l}\text { Patella-Tibia II } \\
\text { Patella-Tibia III }\end{array}$ & $\begin{array}{l}3.69 \\
2.82\end{array}$ & $\begin{array}{l}2.7-4.2 \\
2.4-3.2\end{array}$ \\
\hline $\begin{array}{l}\text { Total } \\
\text { Length }\end{array}$ & 5.98 & $5.1-6.6$ & $\begin{array}{l}\text { Patella-Tibia IV } \\
\text { Total Length IV }\end{array}$ & $\begin{array}{r}3.16 \\
10.46\end{array}$ & $\begin{array}{l}2.8-3.6 \\
9.1-12.0\end{array}$ \\
\hline
\end{tabular}

Color. Female. Face and chelicerae cream to yellow with thin black stripes from AME to distal third of chelicerae as in Figure I3. Lighter color along lower edge of clypeus. Eye region overlaid with white appressed, spatulate-shaped hairs.

Carapace cream to yellow with faint lines radiating from thoracic groove as in Figure I4.

Dorsum of abdomen white to pale yellow, with cardiac area translucent. Mottled with darker colors along sides as in Figure I4. Venter with a broad median dark brown to black stripe from epigastric furrow to base of spinnerets; median stripe outlined by white, becoming darker yellowish laterally.

Legs cream to pale yellow.

Labium and endites cream to yellow. Sternum cream to pale yellow. 
Color. Male. Face and chelicerae cream to yellow with black stripes from AME to distal third of chelicerae as in Figure 76. Eye region black overlaid with white spatulate-shaped hairs.

Carapace cream to yellow with dusky markings as in Figure 77.

Dorsum of abdomen white to cream with darker brown marks along sides as in Figure 77. Venter with wide dark brown or black stripe from genital area to base of spinnerets. Median stripe bounded by white with yellow along sides.

Legs pale yellow to yellow without darker markings or a few scattered black spots, especially on ventral surfaces.

Labium, endites, and sternum cream to yellow.

Diagnosis. Although sharing certain characteristics with other members of the genus Oxyopes, $O$. Alavus is the most divergent member of this group in Mexico and Central America. It is easily distinguished from all other Oxyopes by the bright yellow color contrasted with black markings in living specimens, by its large size, and by the distinct epigynum (Figs. 47-54) and palpus (Figs. I06, 107).

Natural History. Oxyopes flavus was collected in areas of relatively tall ( $3 \mathrm{ft}$. or I $\mathrm{m}$ ) herbaceous vegetation by sweeping. It was relatively abundant in certain habitats where an hour's sweeping by one person would turn up about 20 specimens in the net.

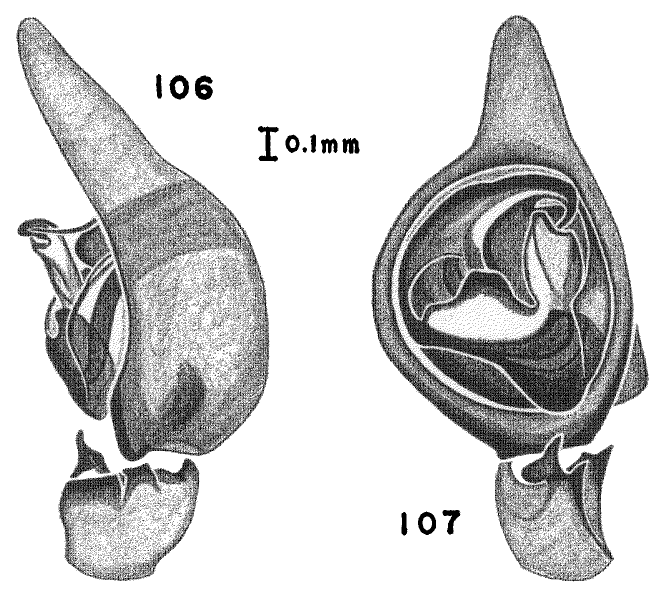

Figs. 106-107. Oxyopes flavus Banks, male from Tierra Colorado, Guerrero, 23 July 1972. 106. Left palpus, retrolateral view. 107. Left palpus, ventral view. 
Distribution. Mexico, mostly along the coastal regions, to Costa Rica (Map 4).

Records. Tamaulipas. I 5 mi. S of Ciudad Victoria, 2 July 1936, $\sigma^{\pi}$ (AMD, LID) ; Villagran, 19 July 1956, $5 \sigma^{7} \sigma^{\pi}$ (VDR, WJG). San Luis Potosi. Valles, 19 July 1956, $0^{\pi}: 3$ 우 (WJG, VDR). Sonora. Alamos, 7 Aug. 1956, + (VDR, WJG). Nayarit. Compostela, $23 \mathrm{mi}$. S of Tepic, I2 July I972, 40o (ARB); San Juan Peyotan, I-3 Aug. 1955, ơ 우우 (BM); Tepic, 2-7 Aug. I947, $30^{x} \sigma^{x}$ : ㅇ o (CG, MG, BM); 20 mi. $\mathrm{N}$ of Tepic, 5 Aug. 1956, $0^{\pi}$ (WJG, VDR). Veracruz. Tierra Colorado, 26 July i956, o (WJG, VDR). Puebla. Acatlan, 24-27 Sept. 1946, ㅇ (HMW). Jalisco. Cihuatlan, I5 July 1972, 80o (ARB, AJ) ; Barranchitas, 31 mi. W of Tequila, I3 July I972, o (ARB); W side of Lake Sayula, 3 Aug. I946, ot (WJG, VDR). Morelos. Cuernavaca, Aug. 1955, + (NLHK) ; 13 mi. E of Cuernavaca, I4 Aug. I954, o (RD). Colima. 20 mi. N of Colima, 2 Aug. 1956, $0^{\pi}$ (VDR, WJG); 7 mi. SE of Manzanillo, I6 July I972, 300 (ARB). Michoacan. $25 \mathrm{mi}$. E of Mazamitla, 2 Aug. 1956, ot:3우 :0o (WJG, VDR). Guerrero. La Garita near Acapulco, I9 Aug. I943, o (D. Peleaez, M. Correa) ; Iguala, 27 Oct. 1947, 3 우우 (HMW) ; Tierra Colorado, 22-23 July 1972, $80^{*} \sigma^{\pi}: 2500$ (ARB). Oaxaca. Oaxaca, 13-20 Oct. I947, † (BM). Chiapas. Los Amates, 6 July 1955, ㅇ (CV, PV); Tonala, Aug. 1909, $0^{\top}: 3$ 우우 (AP). Yucatan. Dolores Otero, I3 July 1952, \& (JCP, DLP); Progreso, 25 July 1952, ơ 우 (JCP, DLP).

HONDURAS. Tegucigalpa, I July 1948, $\sigma^{\top}$ (Clarke).

COSTA RICA. \& (Rogers).

LisT OF COLLECTORS

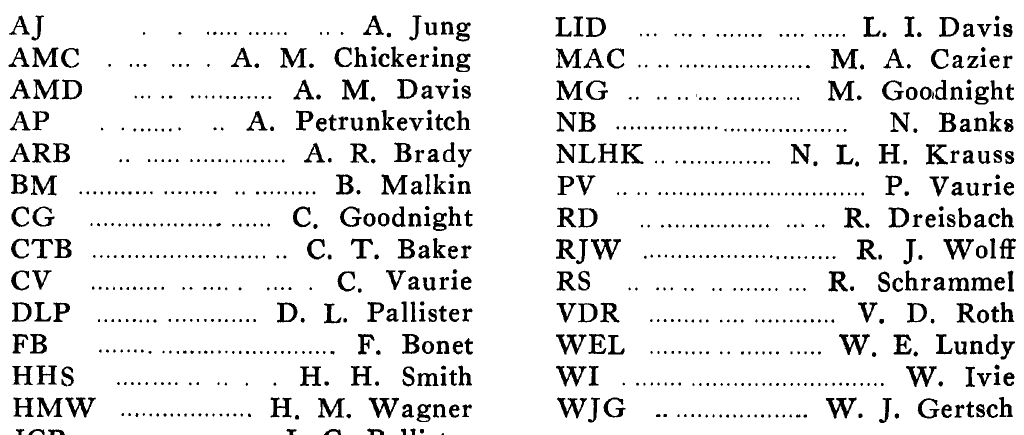




\section{Literature Cited}

BANKs, N.

1898. Arachnida from Baja California, and other parts of Mexico. Proc. Calif. Acad. Sci., $1(3): 278$.

Blackwall, J.

1862. Descriptions of newly discovered spiders captured in Rio Janeiro, by John Gray, Esq., and the Rev. Hamlet Clark. Ann.

BonNet, $P$. Mag. Nat. Hist. (3) $10: 348-360$.

1958. Bibliographia Araneorum. Toulouse, 2(4) :3221-3245.

BRADY, A. R.

1964. The lynx spiders of North America, north of Mexico (Araneae: Oxyopidae). Bull. Mus. Comp. Zool., 131(13) :429-518.

1969. A reconsideration of the Oxyopes apollo species group with the descriptions of two new species (Araneae: Oxyopidae). Psyche, $76(4): 426-438$.

BRYANT, E. B.

1936. New species of southern spiders. Psyche, 36(4):92-93.

1945. Some new or little known southern spiders. Psyche, 52(3-4): 180-182.

Cambridge, F.O.Pickard-

1902. Biologia Centrali-Americana, Arachnida, Araneidea. London, 2:338-346.

Chamberlin, R. V.

1924. The spider fauna of the shores and islands of the Gulf of California. Proc. Calif. Acad. Sci., 12(28):675.

1929. On three new spiders of the genus Oxyopes. Ent. News, 40:17-20. Hentz, N. M.

1845. Descriptions and figures of the Araneides of the United States. Boston Journ. Nat. Hist., $5: 195-197$.

1875. The spiders of the United States. Occ. Pap. Boston Soc. Nat. Hist., 2:45-48.

KeYSERLiNG, E. G.

1877. Ueber amerikanische Spinnenarten der Unterordnung Citigradae. Verh. Zool.-Bot. Ges. Wien, 26:698.

Kraus, $\mathrm{O}$.

1955. Spinnen aus El Salvador (Arachnoidea, Araneae). Abh. senckenb. naturf. Ges., no. $493: 37$.

RoEWER, C. F.

1954. Katalog der Araneae. Bruxelles, $2($ a) :318-334.

Taczanowskr, L.

1873. Les Araneids de la Guyane francaise. Horae Soc. Ent. Ross., $9: 95$. 

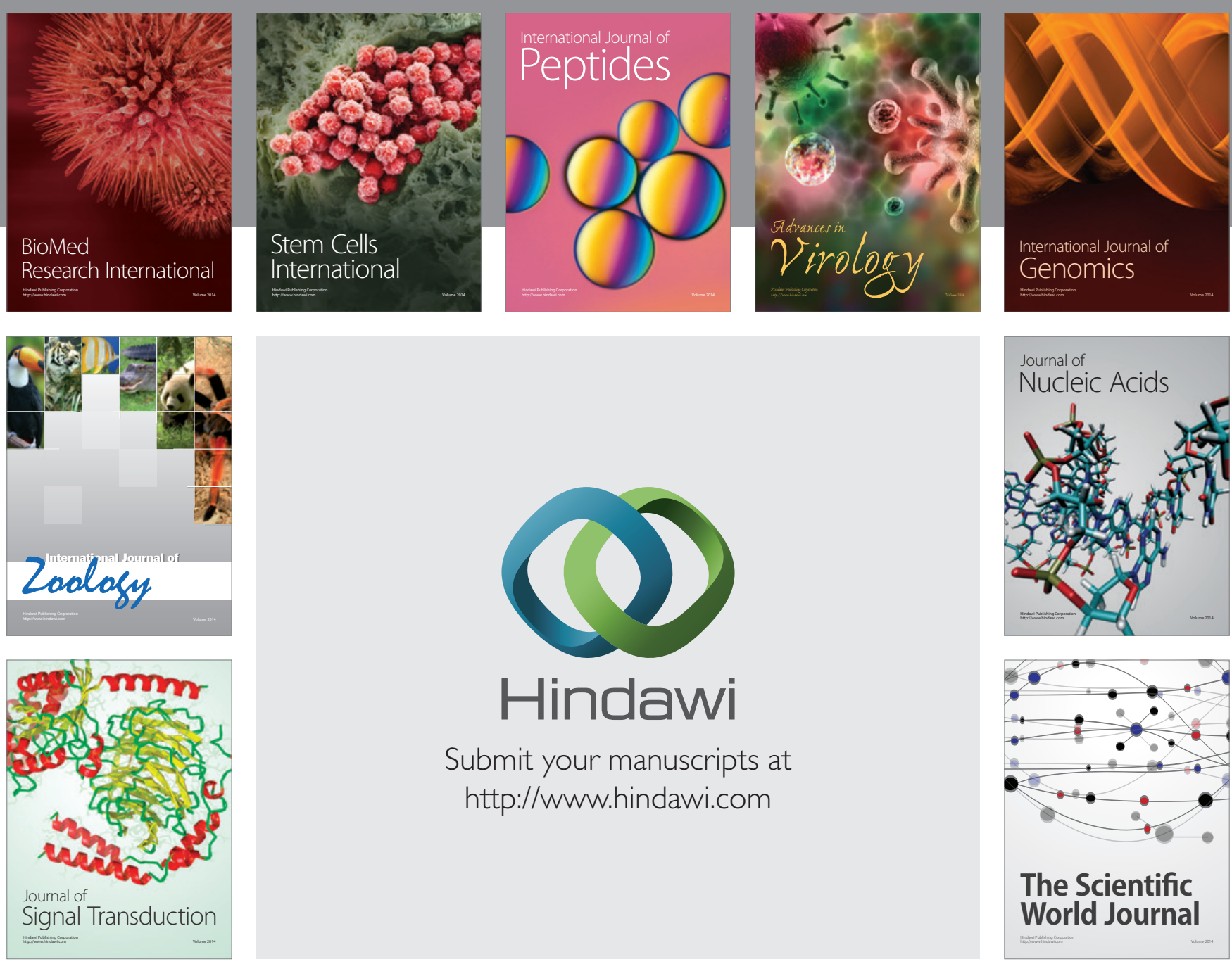

Submit your manuscripts at

http://www.hindawi.com
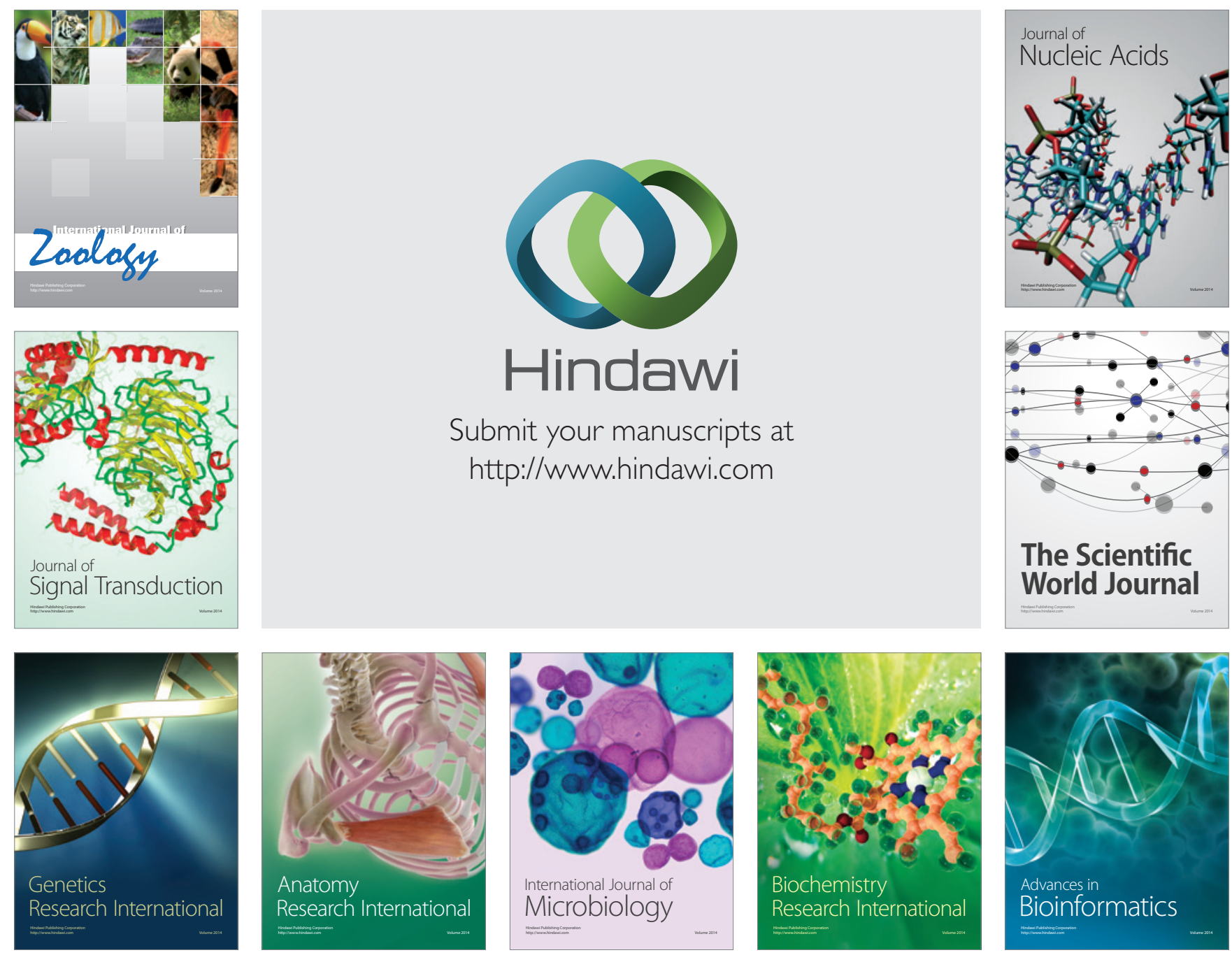

The Scientific World Journal
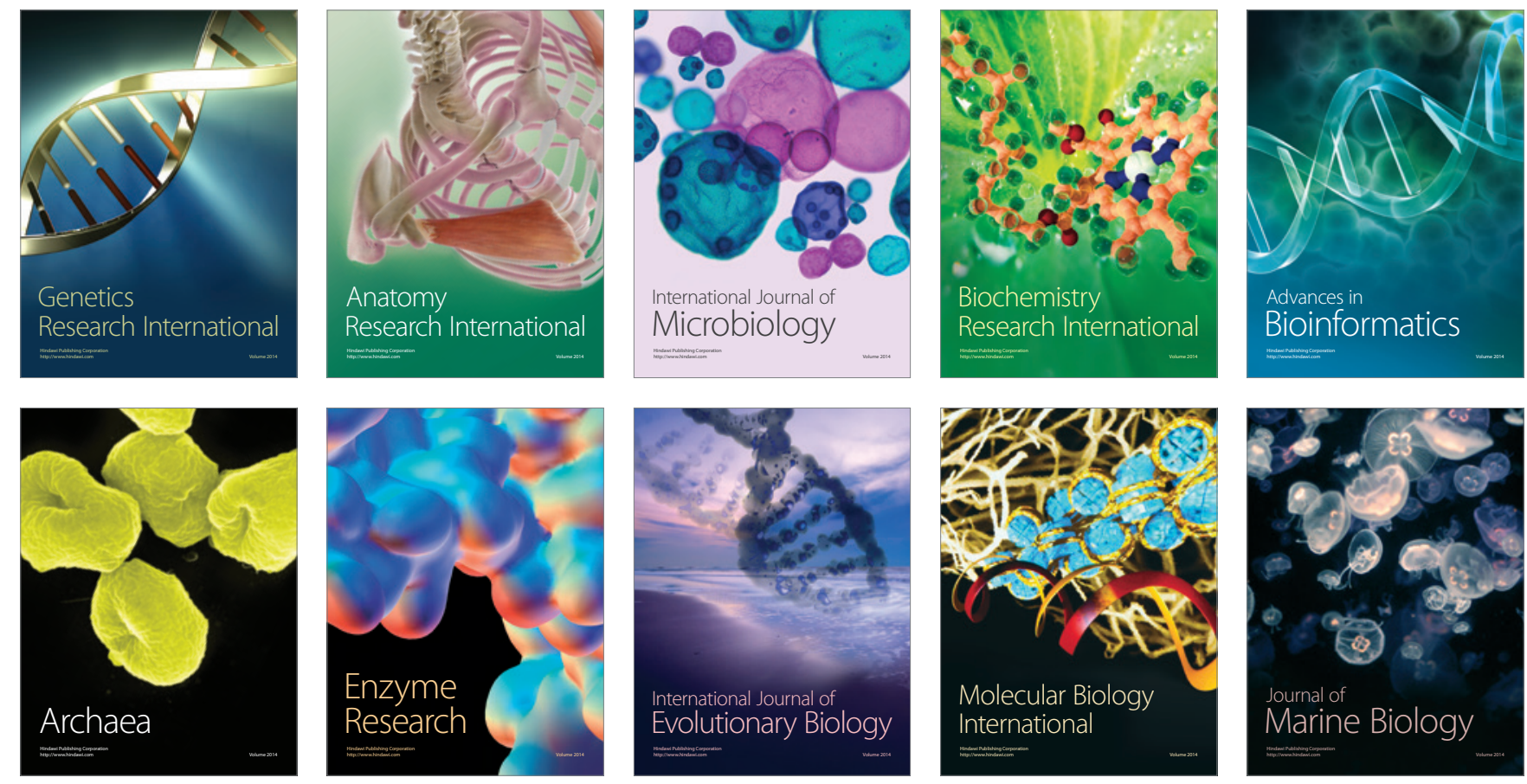